\title{
Morphometric Characteristics and Fin Dimorphism between Male and Female on the Marine Medaka, Oryzias dancena
}

\author{
Jae Hyun Im¹, Hyun Woo Gil², Tae Ho Lee ${ }^{2}$, Hee Jeong Kong ${ }^{3}$, Cheol Min Ahn", \\ Bong Seok Kim ${ }^{4}$, Dong Soo Kim ${ }^{5}$, Chang Ik Zhang ${ }^{6}$ and In-Seok Park ${ }^{2, \dagger}$ \\ ${ }^{1}$ Inland Fisheries Research Institute, National Fisheries Research \& Development Institute, Cheongpyeong 12453, Korea \\ ${ }^{2}$ Division of Marine Environment and Bioscience, College of Ocean Science and Technology, \\ Korea Maritime and Ocean University, Busan 49112, Korea \\ ${ }^{3}$ Biotechnology Research Division, National Fisheries Research \& Development Institute, Busan 46083, Korea \\ ${ }^{4}$ Future Aquaculture Research Center, National Fisheries Research \& Development Institute, Jeju 63610, Korea \\ ${ }^{5}$ Institute of Marine Living Modified Organisms (iMLMO), Pukyong National University, Busan 48513, Korea \\ ${ }^{6}$ Division of Marine Production System Management, College of Fisheries Sciences, \\ Pukyong National University, Busan 48513, Korea
}

\begin{abstract}
Sexual dimorphism is the most conspicuous difference between the sexes. This study examines possible sexual dimorphism and the relative growth patterns of morphometric characteristics in the marine medaka, Oryzias dancena for their potential to help differentiate between males and females of this species. The von Bertalanffy growth parameters estimated by a non-linear regression method were $\mathrm{L}_{\infty}=30.2 \mathrm{~mm}, \mathrm{~K}=3.22 /$ year, and $\tau_{0}=-0.05$. All 18 characteristics measured showed a difference between males and females from 70 days after hatching. Each of these characteristics were significantly different between sexes (ANCOVA, $P<0.05$ ), and the ratio of standard length between sexes showed that males were larger than females for all five morphometric measurements. Fin length measurements were taken for 21 distances of anal fin and 7 distances of dorsal fin between landmarks. There were all differences for all dorsal fin rays between the males and the females and there is significant difference in 70 days after their hatch when the sexual dimorphism is presented. The significant difference $(P<0.05)$ in fin ray for male and female was more greatly seen as they grow. Male marine medaka showed more rapid growth than females, with longer length, dorsal fins and anal fins. Differences in these characteristics will be useful during experiments when it is necessary to differentiate between sexes of marine medaka.
\end{abstract}

Key words : Fin dimorphism, Morphometric characteristics, Oryzias dancena, Sexual dimorphism

\section{INTRODUCTION}

As an experimental fish, the marine medaka, Oryzias dancena, is gaining attention as an experimental animal in aquaculture (Goo et al., 2015). This fish is a euryhaline teleost that can live in both fresh water and seawater (Robert, 1998). It also has a short interval between generations, with spawning possible only 60 days after hatching (Kim et al., 2009b). Kang et al. (2008) and Inoue \& Takei (2003) used the marine medaka to study molecular biomarkers

\footnotetext{
Manuscript received October 23, 2016, Received in revised form November 21, 2016, Accepted December 15, 2016

${ }^{\dagger}$ Corresponding Author : In-Seok Park, Division of Marine Environment and Bioscience, College of Ocean Science and Technology, Korea Maritime and Ocean University, Busan 49112, Korea. Tel. : +82-51-410-4321, Fax : +82-51-404-4750, E-mail : ispark@kmou.ac.kr

Dong Soo Kim, Institute of Marine Living Modified Organisms (iMLMO), Pukyong National University, Busan 48513, Korea, Tel : +82-51-629-7066, Fax : +82-51-629-7067, E-mail : dongskim@pknu.ac.kr
}

This is an Open Access article distributed under the terms of the Creative Commons Attribution Non-Commercial License (http:// creativecommons.org/licenses/by-nc/3.0) which permits unrestricted non-commercial use, distribution, and reproduction in any medium, provided the original work is properly cited. 
and as an experimental fish for adapting to seawater. The marine medaka shows better tolerance than the Japanese medaka, $O$. latipes, in aspects such as survival rates of adult fish and hatched rates of oosperm in hyperosmotic environments (Inoue \& Takei, 2003; Kang et al., 2008).

Recently, the Institute of Marine Living Modified Organisms (iMLMO, Pukyung National University, Korea) selected this species for a living modified organism evaluation project. In line with this purpose, detailed information on its biology (especially early gonadogenesis, sex differentiation, early ontogenesis and embryogenesis) has begun to be examined (Kim et al., 2009a; 2009b). Nam et al. (2010) researched the tolerance capacity to salinity changes in this species and found that the marine medaka was highly capable of hyper-osmoregulation as well as hypo-osmoregulation. Park et al. (2011) examined the effects of clove oil and lidocaine- $\mathrm{HCl}$ on the marine medaka. The results of Park et al. (2011) have contributed to the safe laboratory handling of this species, which is required for many studies.

Both truss (Straüss \& Bookstein, 1982) and classical (Hubb \& Lagler, 1947) dimensions are used to describe fish body shape. Truss dimensions consist of a systematically arranged set of distances that are measured between a set of preselected anatomical landmarks. These landmarks are identified based on local morphological features, and they are chosen to divide the body into functional units (Straüss \& Bond, 1990). Truss dimensions, which include components of body depth and length along the longitudinal axis, have theoretical advantages over classical morphometric characteristics for discriminating among groups (Park et al., 2007, 2015).

Sexual dimorphism is a component of external morphological variation between the sexes, along with features such as the genital papilla, body pigmentation, fin shape (Anderson, 1994). Sexual dimorphism is the most conspicuous difference between the sexes (Kim et al., 2008).
Sexual dimorphism occurs in many fishes. Females are usually larger than males of the same age. In some species, however, males are larger than females, e.g., gudgeon, Gobio gobio (Mann, 1980), and filefish, Brachaluteres ulvarum (Akagawa et al., 1995). The reason for the size difference is not clear (Katano, 1998). Several authors reported that the evolution of larger body size in male likely results from male-male competition associated with a polygynous mating system (Katano, 1998; Kim et al., 2008). Hence, exploring the nature and extent of sexual dimorphism can aid in understanding social structure and adaptation, as well as species identification.

This study examines possible sexual dimorphism and the relative growth patterns of morphometric characteristics in the marine medaka to distinguish between males and females, and we are about to consider more about difference of male and female in morphology seen from anal fin and fin ray as well as dorsal fin.

\section{MATERIALS AND METHODS}

\section{Experimental design}

Marine medaka, Oryzias dancena were reared for this study according to the methods of Park et al. (2011). On 10 August 2015, one hundred offspring of the above generation were separated by sex and habituated in $100 \mathrm{~L}$ glass aquariums for 3 days. The ratio of males to females was 60:40. The culture water was dechlorinated, and 30\% of the water volume in each aquarium was exchanged every day. Brine shrimp, Artemia sp., was collected from the cultured aquarium and provided to the fish every day. Eggs were collected from fish with a standard length over 25 $\mathrm{mm}$. To collect the eggs, 35 male and 15 female marine medakas were placed in each of two aquariums, and 1,000 of their fertilized eggs were collected by net. The fertilized marine medaka eggs were reared in $100 \mathrm{~L}$ glass aquariums. The eggs began to hatch after two weeks, and 60 of the newly hatched fry were fixed in $10 \%$ neutral formalin. 
After hatching, experimental samples were fixed in $10 \%$ neutral formalin according to the determined experimental period ( $n=60 ; 4$ day intervals from 40 days after hatching, 10 day intervals from 70 days after hatching and 20 days intervals from 270 days after hatching). To avoid sampling fish with guts that were distended by large quantities of food, fish were starved for $24 \mathrm{~h}$ before sampling (Park et al., 2001a).

\section{Analysis of morphometric dimorphism between sex}

On 24 June 2016, digital pictures were taken for fixed samples of each group using a Nikon D80 camera $(n=60)$. A scale bar was inserted within the pictures, which were then printed by laser printer (HP laserjet 1010, Epson, Japan). Using the pictures, standard length measurements were taken to the nearest $0.01 \mathrm{~cm}$ using digital vernier calipers (CD-20CP; Mitytoyo, Kawasaki, Japan). Body outline measurements were taken for 19 distances between landmarks for both truss and classical dimensions (Fig. 1, Table 1). Ls, HHAD, and HHAA indicate horizontal distance measurements, while other distances (DHAD, DHDC, DHAA, DHAV, DPAA, DADAA, etc.) indicate direct distance measurements. On 24 August 2016 and 24 October 2016, the standard length and body outline of samples $(n=60$, 330 and 390 days after hatching) were measured using the same method. This study sampled a total of 60 marine medakas, 30 males and 30 females.

Growth was observed between 32 and 390 days after hatching, and standard length, weight and length of characteristics were measured. The von Bertalanffy growth equation employed to describe the growth of marine medakas as follows: $L_{t}=L_{\infty}\left(1-e^{-K\left(t-t_{0}\right)}\right)$. In this equation, $t$ is the age, $L_{\mathrm{t}}$ is the expected length at age $t$ years, $L_{\infty}$ is the asymptotic maximum length, $K$ is the von Bertalanffy growth coefficient and $t_{0}$ is the theoretical age at zero length. These parameters were estimated from a non-linear regression using the EXCEL Solver Software.

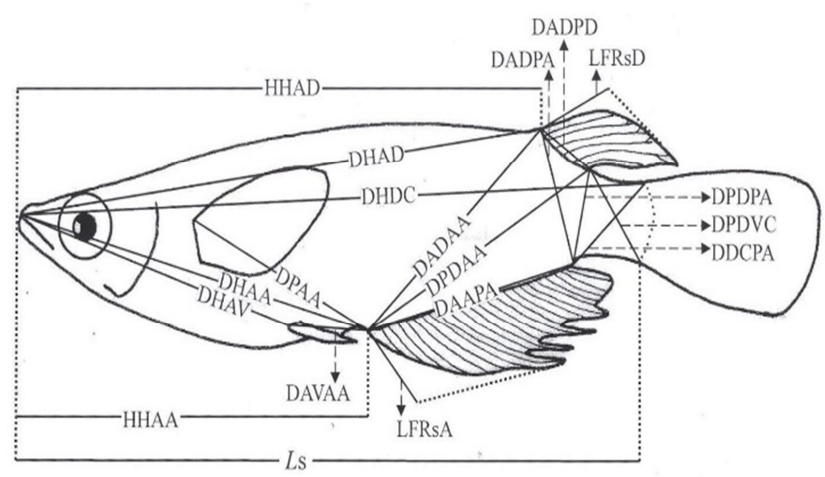

Fig. 1. Morphometric measurements between each landmark for the marine medaka, Oryzias dancena used in this study. For abbreviations, see text.

A $t$-test and an ANCOVA test were both used to determine whether differences between measured male and female parameters were significantly different $(P<0.05, n=60)$. The five most significantly different variables were then used for an ANCOVA test $(n=60)$ to determine which characteristics were most different between males and females. Differences between the methods were regarded as significant at $P<0.05$.

\section{Analysis of fin dimorphism between sex}

On 29 June 2016, anal fin and dorsal fin of fixed samples of each group $(n=60)$ were stained by skeleton staining method (Park et al., 1984). Samples of each group were placed in $5 \mathrm{~mL}$ of $0.5 \% \mathrm{KOH}$ solution and $1-3 \mathrm{~mL}$ of a 3\% $\mathrm{H}_{2} \mathrm{O}_{2}$ solution were added. After 10-20 minutes, all pigmented tissues became transparent. Samples should not be kept in the $\mathrm{H}_{2} \mathrm{O}_{2}$ solution longer than necessary and washed the $\mathrm{H}_{2} \mathrm{O}_{2}$ solution completely out of the specimens with tap water. This is important because residual $\mathrm{H}_{2} \mathrm{O}_{2}$ interferes with staining. Samples were treated with $0.01 \%$ alcian blue 8 GX (Sigma, St. Louis, USA) dissolved in 60 $\mathrm{mL}$ absolute ethanol and $40 \mathrm{~mL}$ glacial acetic acid. Stain for 2 hours. Samples were dehydrated in two changes of absolute ethanol, each 3 hours. Since incomplete dehydration could adversely affect the subsequent alizarine red $\mathrm{S}$ staining. Samples were placed in $10 \mathrm{~mL}$ of $5 \% \mathrm{KOH}$ solu- 
Table 1. Morphometric measurements between each landmark in the marine medaka Oryzias dancena for both truss and classical dimensions

\begin{tabular}{|c|c|}
\hline Ls & Standard length \\
\hline HHAD & $\begin{array}{l}\text { Horizontal distance between the most anterior extension of the head and the anterior insertion of the } \\
\text { first dorsal fin }\end{array}$ \\
\hline HHAA & $\begin{array}{l}\text { Horizontal distance between the most anterior extension of the head and the anterior insertion of the } \\
\text { first anal fin }\end{array}$ \\
\hline DHAD & $\begin{array}{l}\text { Direct distance between the most anterior extension of the head and the anterior insertion of the first } \\
\text { dorsal fin }\end{array}$ \\
\hline DHDC & Direct distance between the most anterior extension of the head and the dorsal base of the caudal fin \\
\hline DHAA & $\begin{array}{l}\text { Direct distance between the most anterior extension of the head and the anterior insertion of the first } \\
\text { anal fin }\end{array}$ \\
\hline DHAV & $\begin{array}{l}\text { Direct distance between the most anterior extension of the head and the anterior insertion of the first } \\
\text { ventral fin }\end{array}$ \\
\hline DPAA & $\begin{array}{l}\text { Direct distance between the dorsal base of the pectoral fin and the anterior insertion of the first anal } \\
\text { fin }\end{array}$ \\
\hline DADAA & $\begin{array}{l}\text { Direct distance between the anterior insertion of the first dorsal fin and the anterior insertion of the } \\
\text { first anal fin }\end{array}$ \\
\hline DPDAA & $\begin{array}{l}\text { Direct distance between the posterior insertion of the last dorsal fin and the anterior insertion of the } \\
\text { first anal fin }\end{array}$ \\
\hline DAAPA & $\begin{array}{l}\text { Direct distance between the anterior insertion of the first anal fin and the posterior insertion of the } \\
\text { last anal fin }\end{array}$ \\
\hline DADPA & $\begin{array}{l}\text { Direct distance between the anterior insertion of the first dorsal fin and the posterior insertion of the } \\
\text { last anal fin }\end{array}$ \\
\hline DADPD & $\begin{array}{l}\text { Direct distance between the anterior insertion of the first dorsal fin and the posterior insertion of the } \\
\text { last dorsal fin }\end{array}$ \\
\hline DPDPA & $\begin{array}{l}\text { Direct distance between the posterior insertion of the last dorsal fin and the posterior insertion of the } \\
\text { last anal fin }\end{array}$ \\
\hline DPDVC & $\begin{array}{l}\text { Direct distance between the posterior insertion of the last dorsal fin and the ventral base of the cau- } \\
\text { dal fin }\end{array}$ \\
\hline DDCPA & $\begin{array}{l}\text { Direct distance between the dorsal base of the caudal fin and the posterior insertion of the last anal } \\
\text { fin }\end{array}$ \\
\hline LFRsD & Length of the fin rays of the dorsal fin \\
\hline LFRsA & Length of the fin rays of the anal fin \\
\hline DAVAA & $\begin{array}{l}\text { Direct distance between the anterior insertion of the first ventral fin and the anterior insertion of the } \\
\text { first anal fin }\end{array}$ \\
\hline
\end{tabular}

tion to which 5 to 10 drops of $0.1 \%$ alizarine red S (Sigma, St. Louis, USA) solution have been added, and samples were stained for 2 hours. Samples were transferred directly to absolute glycerol, and were changed the glycerol every day. Samples were stored in $100 \%$ glycerol containing small crystals of phenol or thymol to prevent bacterial growth.

On 4 July 2016, stained samples of each group ( $n=60$, 30 males and 30 females) were taken a picture with stereo- scopic microscope (Axioskop, Carl Zeiss, Germany) and microscope camera (Axiocam MR, Carl Zeiss, Germany), and a fin was fixed straight by pincette before taking a picture. The pictures were inserted with scale bar and printed by laser printer (HP laserjet 1010, Epson, Japan). Fin length measurements were taken for 21 distances of anal fin (A1 A21) and 7 distances of dorsal fin (D1 D7) between beginning and tip (Fig. 2, Table 2). Fin length measurements of pictures were taken to the nearest $0.01 \mathrm{~mm}$ 


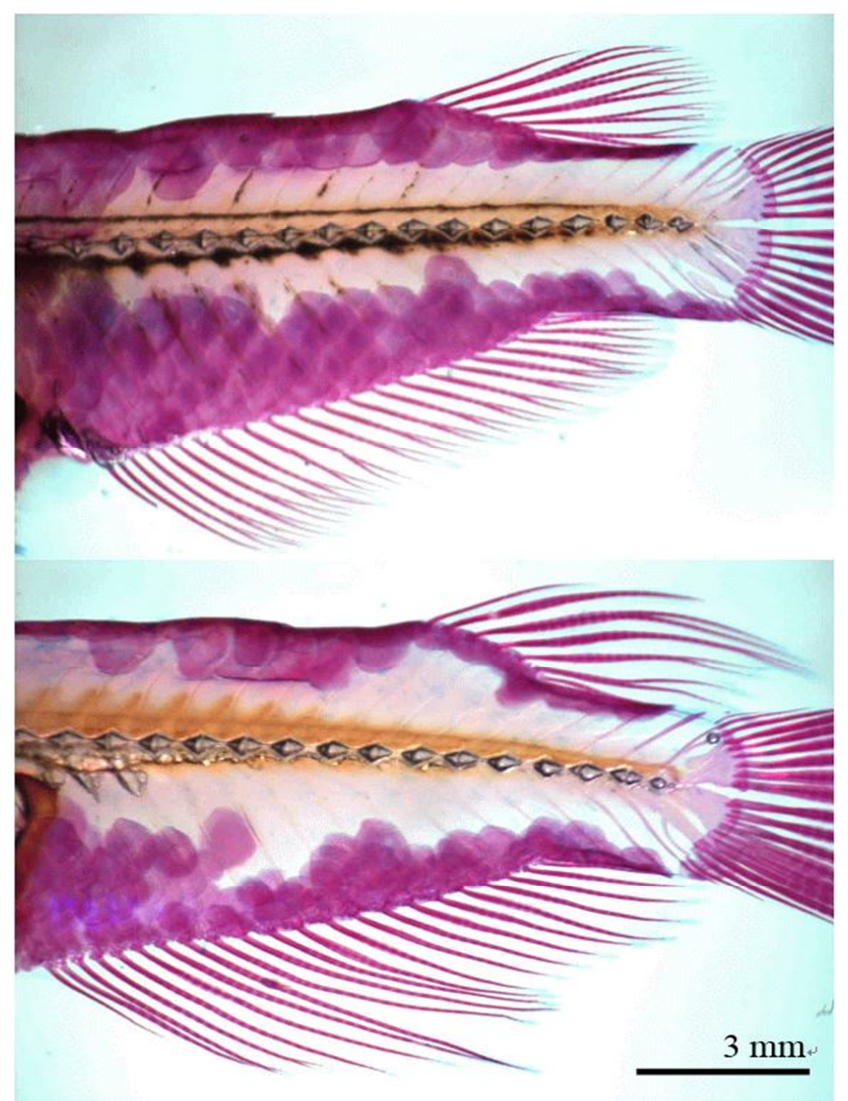

Fig. 2. Fin length measurements from the base to the tip of the dorsal and anal fins of the marine medaka, Oryzias dancena. Samples were stained with Alizarine Red S. Upper: female; lower: male.

using digital vernier calipers (CD-20CP; Mitytoyo, Kawasaki, Japan). All fin length measurements indicate direct distance. On 27 August 2016 and 28 October 2016, the fin length of samples ( $n=60,330$ and $390 \mathrm{DAH})$ from each group were measured using the same method. The differences between males and females were analyzed by $t$-test $(P<0.05, n=60)$ using the SPSS statistics package (SPSS 9.0, SPSS Inc., Chicago, IL, USA). Differences between means were regarded as significant at $P<0.05$.

\section{RESULTS}

\section{Morphometric dimorphism between sex}

The von Bertalanffy growth parameters estimated by the non-linear regression method for marine medaka,

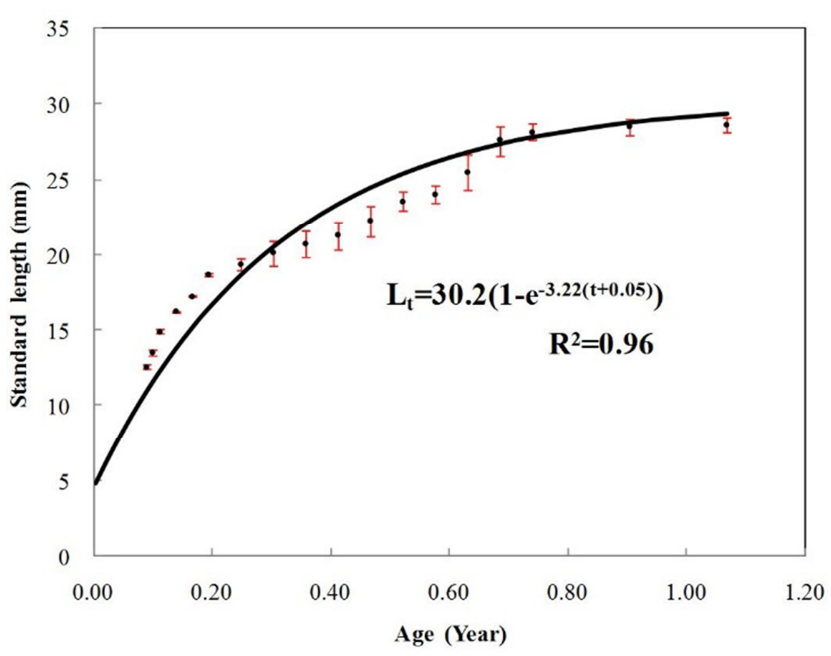

Fig. 3. The von Bertalanffy growth curve by the von Bertalanffy method for the marine medaka, Oryzias dancena. Vertical bars indicate one standard deviation.

Oryzias dancena are shown in Fig. 3. The von Bertalanffy growth equation was $L_{t}=30.2\left(1-e^{-3.22(t-0.05)}\right)$. The growth coefficient $(K)$ is estimated to be 3.22 year, the asymptotic maximum length $\left(L_{\infty}\right)$ is estimated to be $30.2 \mathrm{~mm}$, and the theoretical age at zero length $\left(t_{0}\right)$ is estimated to be -0.05 . For every measured characteristic, significant differences in growth were found between males and females $(P<0.05)$.

The differences in growth between males and females for all 18 characteristics were analyzed with a $t$-test, and the results are shown in Table 3 . Table 3 shows a difference in the growth between males and females in every characteristic from 70 days after hatching. The ANCOVA test shows differences in the direct distance between the anterior insertion of the first dorsal fin and the anterior insertion of the first anal fin (DADAA), the direct distance between the posterior insertion of the last dorsal fin and the anterior of the first anal fin (DPDAA), the direct distance between the anterior insertion of the first dorsal fin and the posterior insertion of the last anal fin (DADPA), the length of the fin rays of the dorsal fin (LFRsD) and the length of the fin rays of the anal fin (LFRsA). The results of the covariance analysis can be found in Table 4. 
Table 2. Fin length measurements from the beginning to the tip of the dorsal fin and anal fin of the marine medaka, Oryzias dancena

\begin{tabular}{|c|c|c|c|c|}
\hline & D1 & First fin ray of dorsal fin & \multirow[t]{7}{*}{ D1 } & \multirow[t]{7}{*}{ D7 } \\
\hline & D2 & Second fin ray of dorsal fin & & \\
\hline & D3 & Third fin ray of dorsal fin & & \\
\hline & D4 & Fourth fin ray of dorsal fin & & \\
\hline & D5 & Fifth fin ray of dorsal fin & & \\
\hline & D6 & Sixth fin ray of dorsal fin & & \\
\hline & D7 & Seventh fin ray of dorsal fin & & \\
\hline A1 & First fin ray of anal fin & Fichth fin rou of onol fin & $A 15$ & Cif onth fin rou of onol fin \\
\hline A2 & Second fin ray fanal fin & 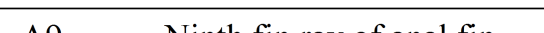 & 16 & $\sigma^{\cdot}$ \\
\hline A2 & Second fin ray of anal fin & Ninth fin ray of anal fin & A16 & Sixteenth fin ray of anal fin \\
\hline A3 & Third fin ray of anal fin & Tenth fin ray of anal fin & A17 & Seventeenth fin ray of anal fin \\
\hline A4 & Fourth fin ray of anal fin & Eleventh fin ray of anal fin & A18 & Eighteenth fin ray of anal fin \\
\hline A5 & Fifth fin ray of anal fin & Twelfth fin ray of anal fin & A19 & Nineteenth fin ray of anal fin \\
\hline A6 & Sixth fin ray of anal fin & Thirteenth fin ray of anal fin & A20 & Twentieth fin ray of anal fin \\
\hline A7 & Seventh fin ray of anal fin & Fourteenth fin ray of anal fin & $\mathrm{A} 21$ & Twenty-first fin ray of anal fin \\
\hline
\end{tabular}

Table 3. Results of the Student's $t$-test for differences in 18 characteristics between male and female of marine medaka, Oryzias dancena by days after hatched"

\begin{tabular}{cccccccccc}
\hline \hline Day & HHAD & HHAA & DHAD & DHDC & DHAA & DHAV & DPAA & DADAA & DPDAA \\
\hline 70 & $2.22 \mathrm{E}-12^{* * *}$ & $7.56 \mathrm{E}-10^{* * *}$ & $1.25 \mathrm{E}-12^{* * *}$ & $6.34 \mathrm{E}-12^{* * *}$ & $6.09 \mathrm{E}-14^{* * *}$ & $7.94 \mathrm{E}-11^{* * *}$ & $1.83 \mathrm{E}-10^{* * *}$ & $1.26 \mathrm{E}-26^{* * *}$ & $1.46 \mathrm{E}-16^{* * *}$ \\
90 & $3.11 \mathrm{E}-19^{* * *}$ & $2.32 \mathrm{E}-19^{* * *}$ & $5.70 \mathrm{E}-18^{* * *}$ & $1.33 \mathrm{E}-18^{* * *}$ & $4.21 \mathrm{E}-18^{* * *}$ & $1.23 \mathrm{E}-19^{* * *}$ & $2.87 \mathrm{E}-19^{* * *}$ & $5.60 \mathrm{E}-27^{* * *}$ & $2.63 \mathrm{E}-21^{* * *}$ \\
110 & $4.59 \mathrm{E}-44^{* * *}$ & $3.57 \mathrm{E}-46^{* * *}$ & $2.94 \mathrm{E}-40^{* * *}$ & $4.96 \mathrm{E}-45^{* * *}$ & $4.16 \mathrm{E}-39^{* * *}$ & $2.79 \mathrm{E}-37^{* * *}$ & $1.33 \mathrm{E}-43^{* * *}$ & $2.09 \mathrm{E}-33^{* * *}$ & $3.41 \mathrm{E}-43^{* * *}$ \\
130 & $1.13 \mathrm{E}-43^{* * *}$ & $2.40 \mathrm{E}-42^{* * *}$ & $8.13 \mathrm{E}-45^{* * *}$ & $4.79 \mathrm{E}-44^{* * *}$ & $2.89 \mathrm{E}-42^{* * *}$ & $1.05 \mathrm{E}-40^{* * *}$ & $2.57 \mathrm{E}-41^{* * *}$ & $2.38 \mathrm{E}-44^{* * *}$ & $6.85 \mathrm{E}-45^{* * *}$ \\
150 & $4.33 \mathrm{E}-42^{* * *}$ & $1.20 \mathrm{E}-46^{* * *}$ & $3.58 \mathrm{E}-47^{* * *}$ & $2.58 \mathrm{E}-48^{* * *}$ & $1.70 \mathrm{E}-46^{* * *}$ & $1.15 \mathrm{E}-42^{* * *}$ & $1.28 \mathrm{E}-42^{* * *}$ & $4.24 \mathrm{E}-42^{* * *}$ & $6.32 \mathrm{E}-53^{* * *}$ \\
170 & $8.06 \mathrm{E}-38^{* * *}$ & $4.69 \mathrm{E}-38^{* * *}$ & $1.17 \mathrm{E}-37^{* * *}$ & $9.98 \mathrm{E}-40^{* * *}$ & $6.19 \mathrm{E}-40^{* * *}$ & $9.63 \mathrm{E}-38^{* * *}$ & $1.32 \mathrm{E}-39^{* * *}$ & $4.65 \mathrm{E}-35^{* * *}$ & $2.05 \mathrm{E}-42^{* * *}$ \\
\hline
\end{tabular}


Table 3. Continued

\begin{tabular}{|c|c|c|c|c|c|c|c|c|c|}
\hline Day & HHAD & HHAA & DHAD & DHDC & DHAA & DHAV & DPAA & DADAA & DPDAA \\
\hline 190 & $1.93 \mathrm{E}-35^{* * *}$ & $1.32 \mathrm{E}-34^{* * *}$ & $1.64 \mathrm{E}-32^{* * *}$ & $1.35 \mathrm{E}-34^{* * *}$ & $2.13 \mathrm{E}-33^{* * *}$ & $2.40 \mathrm{E}-29^{* * *}$ & $2.94 \mathrm{E}-31^{* * *}$ & $2.21 \mathrm{E}-40^{* * *}$ & $8.82 \mathrm{E}-42^{* * *}$ \\
\hline 210 & $6.48 \mathrm{E}-37^{* * *}$ & $3.25 \mathrm{E}-36^{* * *}$ & $1.23 \mathrm{E}-33^{* * *}$ & $5.45 \mathrm{E}-36^{* * *}$ & $3.65 \mathrm{E}-26^{* * *}$ & $3.03 \mathrm{E}-30^{* * *}$ & $1.66 \mathrm{E}-32^{* * *}$ & $9.00 \mathrm{E}-49^{* * *}$ & $1.40 \mathrm{E}-41^{* * *}$ \\
\hline 230 & $6.61 \mathrm{E}-43^{* * *}$ & $1.56 \mathrm{E}-41^{* * *}$ & $4.36 \mathrm{E}-38^{* * *}$ & $4.57 \mathrm{E}-42^{* * *}$ & $5.23 \mathrm{E}-38^{* * *}$ & $1.86 \mathrm{E}-39^{* * *}$ & $7.61 \mathrm{E}-41^{* * *}$ & $7.34 \mathrm{E}-44^{* * *}$ & $3.29 \mathrm{E}-49^{* * *}$ \\
\hline 250 & $1.30 \mathrm{E}-34^{* * *}$ & $4.35 \mathrm{E}-33^{* * *}$ & $1.74 \mathrm{E}-31^{* * *}$ & $9.14 \mathrm{E}-37^{* * *}$ & $3.14 \mathrm{E}-35^{* * *}$ & $1.65 \mathrm{E}-37^{* * *}$ & $3.70 \mathrm{E}-34^{* * *}$ & $1.40 \mathrm{E}-45^{* * *}$ & $1.69 \mathrm{E}-41^{* * *}$ \\
\hline 270 & 1.29E-26 & 7.99E-31 $1^{* * *}$ & $6.31 \mathrm{E}-33^{* * *}$ & $2.22 \mathrm{E}-37^{* * *}$ & $4.76 \mathrm{E}-32^{* * *}$ & $4.86 \mathrm{E}-34^{* * *}$ & $5.92 \mathrm{E}-29^{* * *}$ & $3.00 \mathrm{E}-49^{* * *}$ & $1.12 \mathrm{E}-47^{* * *}$ \\
\hline 330 & $2.27 \mathrm{E}-32^{* * *}$ & $2.70 \mathrm{E}-40^{* * *}$ & $9.31 \mathrm{E}-30^{* * *}$ & $1.98 \mathrm{E}-40^{* * *}$ & $4.05 \mathrm{E}-33^{* * *}$ & $2.78 \mathrm{E}-27^{* * *}$ & $3.35 \mathrm{E}-36^{* * *}$ & $5.71 \mathrm{E}-52^{* * *}$ & $1.43 \mathrm{E}-45^{* * *}$ \\
\hline 390 & 2.62E-31 $1^{* * *}$ & $2.66 \mathrm{E}-39^{* * *}$ & $9.78 \mathrm{E}-31^{* * *}$ & $1.91 \mathrm{E}-37^{* * *}$ & $3.09 \mathrm{E}-32^{* * *}$ & $4.90 \mathrm{E}-26^{* * *}$ & $6.90 \mathrm{E}-34^{* * *}$ & $1.56 \mathrm{E}-49^{* * *}$ & $5.19 \mathrm{E}-46^{* * *}$ \\
\hline Day & DAAPA & DADPA & DADPD & DPDPA & DPDVC & DDCPA & LFRsD & LFRsA & DAVAA \\
\hline 70 & $1.70 \mathrm{E}-12^{* * *}$ & $6.38 \mathrm{E}-06^{* * *}$ & $1.52 \mathrm{E}-05^{* * *}$ & $0.0141^{* * *}$ & $5.01 \mathrm{E}-05^{* * *}$ & $0.0006^{* * *}$ & $1.06 \mathrm{E}-18^{* * *}$ & $2.36 \mathrm{E}-08^{* * *}$ & $7.95 \mathrm{E}-05^{* * *}$ \\
\hline 90 & $8.79 \mathrm{E}-18^{* * *}$ & $7.15 \mathrm{E}-18^{* * *}$ & $5.52 \mathrm{E}-15^{* * *}$ & $5.66 \mathrm{E}-15^{* * *}$ & $1.15 \mathrm{E}-16^{* * *}$ & $4.01 \mathrm{E}-14^{* * *}$ & 4.24E- $24^{* * *}$ & $5.33 \mathrm{E}-14^{* * *}$ & $1.20 \mathrm{E}-16^{* * *}$ \\
\hline 110 & $2.18 \mathrm{E}-45^{* * *}$ & $8.39 \mathrm{E}-30^{* * *}$ & $4.16 \mathrm{E}-31^{* * *}$ & $1.68 \mathrm{E}-26^{* * *}$ & $1.51 \mathrm{E}-27^{* * *}$ & $2.44 \mathrm{E}-26^{* * *}$ & $6.34 \mathrm{E}-47^{* * *}$ & $5.08 \mathrm{E}-27^{* * *}$ & $6.13 \mathrm{E}-28^{* * *}$ \\
\hline 130 & $3.09 \mathrm{E}-39^{* * *}$ & 7.47E-38 $8^{* * *}$ & $1.19 \mathrm{E}-26^{* * *}$ & 1.84E-24 $4^{* * *}$ & $9.81 \mathrm{E}-33^{* * *}$ & $4.37 \mathrm{E}-25^{* * *}$ & $1.37 \mathrm{E}-49^{* * *}$ & $2.08 \mathrm{E}-27^{* * *}$ & $2.94 \mathrm{E}-34^{* * *}$ \\
\hline 150 & $1.25 \mathrm{E}-44^{* * *}$ & $3.40 \mathrm{E}-40^{* * *}$ & $3.59 \mathrm{E}-27^{* * *}$ & $5.93 \mathrm{E}-33^{* * *}$ & $2.05 \mathrm{E}-35^{* * *}$ & $9.96 \mathrm{E}-37^{* * *}$ & $2.89 \mathrm{E}-41^{* * *}$ & $4.96 \mathrm{E}-27^{* * *}$ & $1.36 \mathrm{E}-37^{* * *}$ \\
\hline 170 & $7.11 \mathrm{E}-32^{* * *}$ & $5.47 \mathrm{E}-29^{* * *}$ & $1.30 \mathrm{E}-27^{* * *}$ & $1.30 \mathrm{E}-32^{* * *}$ & $1.80 \mathrm{E}-26^{* * *}$ & $1.73 \mathrm{E}-33^{* * *}$ & $1.26 \mathrm{E}-37^{* * *}$ & $4.54 \mathrm{E}-24^{* * *}$ & $7.70 \mathrm{E}-27^{* * *}$ \\
\hline 190 & $1.95 \mathrm{E}-27^{* * *}$ & $1.30 \mathrm{E}-38^{* * *}$ & $2.07 \mathrm{E}-23^{* * *}$ & $8.98 \mathrm{E}-27^{* * *}$ & $1.17 \mathrm{E}-28^{* * *}$ & $1.47 \mathrm{E}-29^{* * *}$ & $3.43 \mathrm{E}-33^{* * *}$ & $4.23 \mathrm{E}-27^{* * *}$ & $1.24 \mathrm{E}-28^{* * *}$ \\
\hline 210 & $1.06 \mathrm{E}-28^{* * *}$ & $3.43 \mathrm{E}-30^{* * *}$ & $1.94 \mathrm{E}-23^{* * *}$ & $4.92 \mathrm{E}-25^{* * *}$ & $1.36 \mathrm{E}-29^{* * *}$ & $2.35 \mathrm{E}-26^{* * *}$ & $5.73 \mathrm{E}-25^{* * *}$ & $2.00 \mathrm{E}-34^{* * *}$ & $4.84 \mathrm{E}-28^{* * *}$ \\
\hline 230 & $5.39 \mathrm{E}-34^{* * *}$ & $3.76 \mathrm{E}-33^{* * *}$ & $4.55 \mathrm{E}-33^{* * *}$ & 3.27E-34 $4^{* * *}$ & $9.11 \mathrm{E}-34^{* * *}$ & $3.46 \mathrm{E}-34^{* * *}$ & $2.24 \mathrm{E}-28^{* * *}$ & $3.67 \mathrm{E}-34^{* * *}$ & $1.89 \mathrm{E}-33^{* * *}$ \\
\hline 250 & $5.93 \mathrm{E}-30^{* * *}$ & $7.48 \mathrm{E}-32^{* * *}$ & $1.13 \mathrm{E}-29^{* * *}$ & $7.24 \mathrm{E}-30^{* * *}$ & $2.10 \mathrm{E}-22^{* * *}$ & $2.55 \mathrm{E}-31^{* * *}$ & $6.32 \mathrm{E}-28^{* * *}$ & $3.65 \mathrm{E}-36^{* * *}$ & $5.78 \mathrm{E}-23^{* * *}$ \\
\hline 270 & $1.33 \mathrm{E}-27^{* * *}$ & $2.49 \mathrm{E}-29^{* * *}$ & $1.30 \mathrm{E}-18^{* * *}$ & $1.77 \mathrm{E}-17^{* * *}$ & $1.12 \mathrm{E}-24^{* * *}$ & $8.57 \mathrm{E}-18^{* * *}$ & $2.90 \mathrm{E}-26^{* * *}$ & $5.50 \mathrm{E}-33^{* * *}$ & $1.27 \mathrm{E}-24^{* * *}$ \\
\hline 330 & $1.70 \mathrm{E}-30^{* * *}$ & $7.90 \mathrm{E}-30^{* * *}$ & $3.38 \mathrm{E}-28^{* * *}$ & $1.92 \mathrm{E}-18^{* * *}$ & 2.34E-29 $9^{* * *}$ & $1.92 \mathrm{E}-18^{* * *}$ & $3.30 \mathrm{E}-26^{* * *}$ & $4.58 \mathrm{E}-34^{* * *}$ & $1.07 \mathrm{E}-24^{* * *}$ \\
\hline 390 & $7.80 \mathrm{E}-30^{* * *}$ & $2.73 \mathrm{E}-29^{* * *}$ & $4.48 \mathrm{E}-27^{* * *}$ & $1.02 \mathrm{E}-17^{* * *}$ & $8.79 \mathrm{E}-28^{* * *}$ & $3.86 \mathrm{E}-18^{* * *}$ & $1.28 \mathrm{E}-26^{* * *}$ & $4.68 \mathrm{E}-35^{* * *}$ & $5.23 \mathrm{E}-23^{* * *}$ \\
\hline
\end{tabular}

*For abbreviations, see Table 1. The sample numbers of males and females are 30 and 30, respectively. ${ }^{*} P<0.05 ;{ }^{* *} P<0.01 ;{ }^{* * *} P<0.001$; NS, not significant. 
Table 4. Test for differences of regression coefficients between males and females by 5 characteristics of the marine medaka Oryzias dancena*

\begin{tabular}{cccccc}
\hline \hline Statistics & DADAA & DPDAA & DADPA & LFRsD & LFRsA \\
\hline $\mathrm{b}_{\mathrm{m}}$ & 0.3705 & 0.3953 & 0.1743 & 0.1023 & 0.1177 \\
$\mathrm{~b}_{\mathrm{f}}$ & 0.3335 & 0.3811 & 0.1621 & 0.0866 & 0.0961 \\
Residual SS $\mathrm{m}_{\mathrm{m}}$ & 54.54 & 13.35 & 29.30 & 18.27 & 37.62 \\
Residual SS $\mathrm{f}_{\mathrm{f}}$ & 4.07 & 0.73 & 3.20 & 6.26 & 2.69 \\
Residual DF & 538 & 538 & 538 & 538 & 538 \\
Residual DF $_{\mathrm{f}}$ & 538 & 538 & 538 & 538 & 538 \\
$\mathrm{~s}_{\mathrm{m}-\mathrm{f}}$ & 0.0007 & 0.0003 & 0.0005 & 0.0005 & 0.0006 \\
$\mathrm{t}$ & 53.0692 & 41.4923 & 23.6211 & 34.7538 & 37.2436 \\
$\mathrm{v}$ & 1076 & 1076 & 1076 & 1076 & 1076 \\
$\mathrm{t}_{0.05(2), 1076}$ & 1.9600 & 1.9600 & 1.9600 & 1.9600 & 1.9600 \\
$P$ & $<0.05$ & $<0.05$ & $<0.05$ & $<0.05$ & $<0.05$ \\
\hline
\end{tabular}

*For abbreviations, see Table 1.

Five measured characteristics showed significant differences between sexes $(P<0.05)$. When relating the characteristics to the standard length of the fishes, males had significantly larger measurements than females for all five characteristics (Figs. 4 and 5). For DADAA, the difference in the slope of the equation between males and females was larger than in the slopes for DPDAA or DADPA. In other words, between the three characteristics, DADAA had the most significant difference between males and females. For LFRsA, the difference in the slope of the equation between males and females was larger than those in LFRsD $(P<0.05)$, with both dorsal fin and anal fin lengths being longer in males than females. Naked eye observations also confirmed these findings (Fig. 6).

\section{Fin dimorphism between sex}

The difference in each fin ray length of male and female dorsal fin is shown in Table 5. There were all differences from dorsal fin 1 (D1) to D7 for all fin rays from males and females and there is significant difference in 70 days after hatched (DAH) when the sexual dimorphism is presented.

The significant difference in fin ray for male and female was more greatly seen as they grow. The consistent growth until $70 \mathrm{DAH}$ from the fin rays of all dorsal fins then the rapid growth since $170 \mathrm{DAH}$ and the flat growth since $250 \mathrm{DAH}$ were seen. The difference of each fin ray from anal fin of male and female is seen in Table 6. There was difference for male and female in all fin rays from anal fin 1 (A1) to A22. There was a significant difference since $70 \mathrm{DAH}$ when the sexual dimorphism appears and they become more sig 

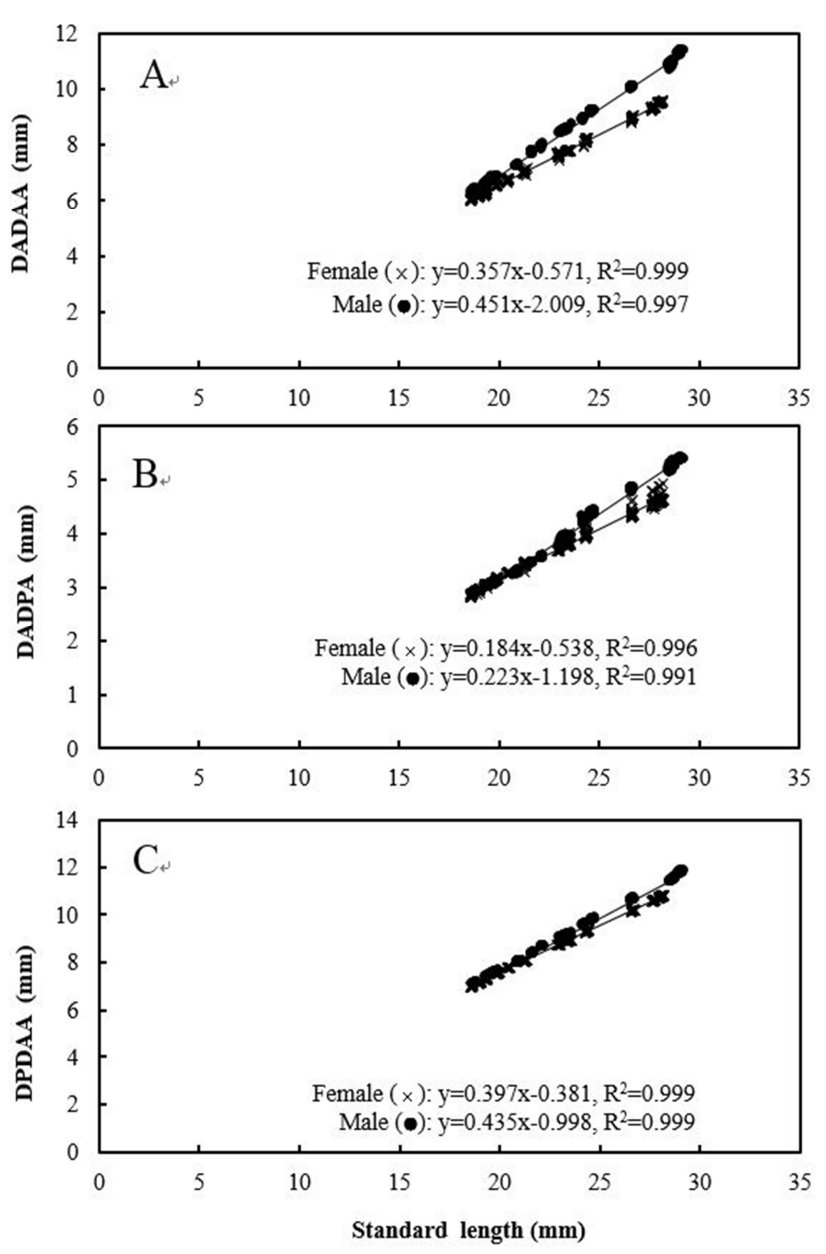

Fig. 4. The relationship among standard length and direct distance (A) the anterior insertion of the first dorsal fin and the anterior insertion of the first anal fin (DADAA), (B) the posterior insertion of the last dorsal fin and the anterior insertion of the first anal fin (DPDAA) and (C) the anterior insertion of the first dorsal fin and the posterior insertion of the last anal fin (DADPA) in marine medaka, Oryzias dancena. x: female; $\bullet$ : male.

nificant difference as they grow $(P<0.05)$. The consistent growth until $70 \mathrm{DAH}$ from the fin rays of all dorsal fin then the rapid growth since $170 \mathrm{DAH}$ and the flat growth since 210 DAH were seen.

The separation which the anal and dorsal fins of fin rays becomes two fin rays was seen from both male and female and the trend of separation had differences in male and female which is presented in Table 7. For female, all fin
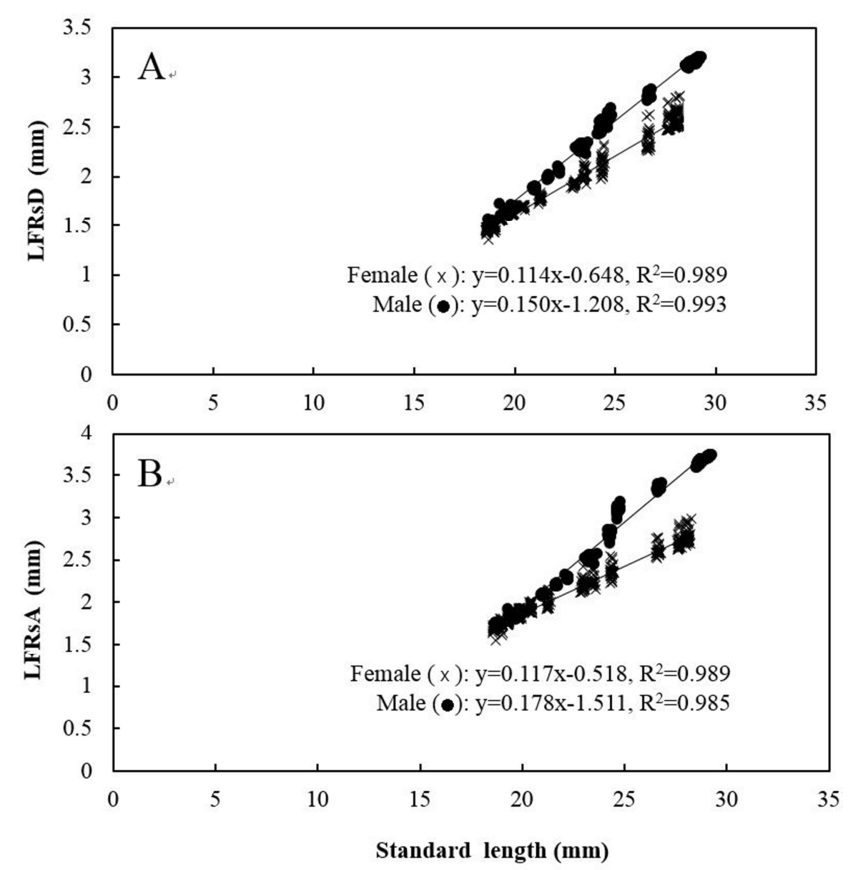

Fig. 5. The relationship among standard length and length of (A) the fin rays of the dorsal fin (LFRsD) and $(B)$ the fin rays of the anal fin (LFRsA) in marine medaka, Oryzias dancena. $\mathrm{x}$ : female; $\bullet$ : male.

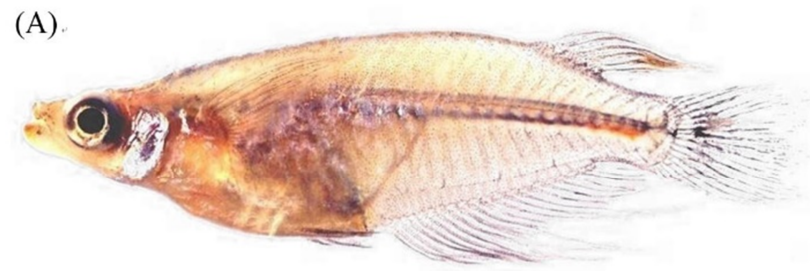

(B)

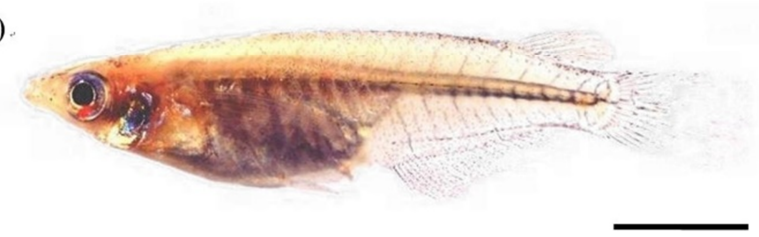

Fig. 6. Pictures of the marine medaka, Oryzias dancena. Samples in this picture had grown 270 days after hatching. (A): male; (B): female. Bar indicates $0.5 \mathrm{~cm}$.

rays of dorsal fin since $70 \mathrm{DAH}$ showed separation and the separated fin rays gradually grew as time flows $(p<0.05)$. For male, they did not show separation until the $190 \mathrm{DAH}$ and it was witnessed on $190 \mathrm{DAH}$ and after for A1-4 and A19-21 fin rays. The separated fin rays grew as time flows $(p<0.05)$. 
Table 5. Results of Student's $\boldsymbol{t}$-test for differences in 7 dorsal fin distance between male ( $⿱$ ) ) and female ( $q$ ) of marine medaka, Oryzias dancena by days after hatched*

\begin{tabular}{|c|c|c|c|c|c|c|c|}
\hline $\begin{array}{c}\text { Days after } \\
\text { hatched }\end{array}$ & 32 & 70 & 110 & 150 & 190 & 230 & 270 \\
\hline & $1.06 \pm 0.33^{\mathrm{a}}$ & $1.17 \pm 0.24^{\mathrm{a}} 1.80 \pm 0.43^{\mathrm{a}}$ & & $2.17 \pm 0.43^{\mathrm{a}}$ & & & $3.24 \pm 0.70^{\mathrm{a}} 3.25 \pm 0.70$ \\
\hline D1 ( $q)$ & $02 \pm 0.48^{b}$ & $.14 \pm 0.34^{\mathrm{b}} 1.60 \pm 0.42^{\mathrm{b}}$ & $1.81 \pm 0.49^{b}$ & $2.00 \pm 0.48^{b}$ & & & $2.62 \pm 0.77^{\mathrm{b}} 2.70 \pm 0.86$ \\
\hline D2 (ふ) & $1.44 \pm 0.28^{\mathrm{a}}$ & $1.56 \pm 0.33^{\mathrm{a}} 2.66 \pm 0.46^{\mathrm{a}}$ & $3.04 \pm 0.44^{\mathrm{a}}$ & $3.27 \pm 0.67^{\mathrm{a}}$ & $3.69 \pm 0.52^{\mathrm{a}}$ & $4.27 \pm 0.58^{\mathrm{a}}$ & $4.80 \pm 0.67^{\mathrm{a}} 4.85 \pm 0.72^{\mathrm{a}}$ \\
\hline D2 (q) & $1.44 \pm 0.49^{\mathrm{b}}$ & $1.54 \pm 0.36^{\mathrm{b}} 2.26 \pm 0.51^{\mathrm{b}}$ & $2.72 \pm 0.55^{b}$ & $2.85 \pm 0.62^{b}$ & $3.13 \pm 0.53^{b}$ & $3.63 \pm 0$ & $4.07 \pm 0.51^{\mathrm{b}} 4.08 \pm 0.58$ \\
\hline D3 $\left(ठ^{\Uparrow}\right)$ & $1.43 \pm 0.56^{\mathrm{a}}$ & $1.64 \pm 0.38^{\mathrm{a}} 3.01 \pm 0.53^{\mathrm{a}}$ & $3.42 \pm 0.59^{\mathrm{a}}$ & $3.65 \pm 0.51^{\mathrm{a}}$ & $4.56 \pm 0.66^{\mathrm{a}}$ & $5.07 \pm 0.59^{\mathrm{a}}$ & $5.86 \pm 0.79^{\mathrm{a}} 6.26 \pm 0.72^{\mathrm{a}}$ \\
\hline D3 (우) & $1.43 \pm 0.59^{b}$ & $1.63 \pm 0.33^{\mathrm{b}} 2.23 \pm 0.55^{\mathrm{b}}$ & $2.77 \pm 0.55^{\mathrm{b}}$ & $2.90 \pm 0.53^{b}$ & & & $4.01 \pm 0.80^{\mathrm{b}} 4.61 \pm 0.79^{\mathrm{b}}$ \\
\hline D4 (ठ゚) & $1.46 \pm 0.51^{\mathrm{a}}$ & $1.60 \pm 0.29^{\mathrm{a}} 2.72 \pm 0.59^{\mathrm{a}}$ & $3.15 \pm 0.56^{\mathrm{a}}$ & $3.48 \pm 0.48^{\mathrm{a}}$ & $4.05 \pm 0.60^{\mathrm{a}}$ & $4.73 \pm 0.71^{\mathrm{a}}$ & $5.70 \pm 0.70^{\mathrm{a}} 5.86 \pm 0.74^{\mathrm{a}}$ \\
\hline D4 (ㅇ) & & $1.48 \pm 0.40^{\mathrm{b}} 2.13 \pm 0.54^{\mathrm{b}}$ & $2.58 \pm 0.48^{\mathrm{b}}$ & & $2.92 \pm 0.61^{b}$ & $3.43 \pm 0.77^{b}$ & $4.10 \pm 0.60^{\mathrm{b}} 4.40 \pm 0.79^{\mathrm{b}}$ \\
\hline D5 $(ठ)$ & $1.18 \pm 0.39^{\mathrm{a}}$ & $1.38 \pm 0.30^{\mathrm{a}} 2.16 \pm 0.57^{\mathrm{a}}$ & $2.41 \pm 0.61^{\mathrm{a}}$ & $2.52 \pm 0.43^{\mathrm{a}}$ & $2.95 \pm 0.49^{\mathrm{a}}$ & $3.51 \pm 0.72^{\mathrm{a}}$ & $4.15 \pm 0.68^{\mathrm{a}} 4.28 \pm 0.73^{\mathrm{a}}$ \\
\hline D5 (q) & $1.17 \pm 0.58^{b}$ & $1.25 \pm 0.35^{\mathrm{b}} 1.78 \pm 0.49^{\mathrm{b}}$ & $2.16 \pm 0.54^{b}$ & $2.29 \pm 0.65^{b}$ & $2.53 \pm 0.51^{b}$ & $3.02 \pm 0.41^{\mathrm{b}}$ & $3.18 \pm 0.66^{\mathrm{b}} 3.26 \pm 0.62^{\mathrm{b}}$ \\
\hline D6 (ठ゚) & $0.69 \pm 0.10^{\mathrm{a}}$ & $1.07 \pm 0.34^{\mathrm{a}} 1.70 \pm 0.61^{\mathrm{a}}$ & $1.96 \pm 0.68^{\mathrm{a}}$ & $2.15 \pm 0.48^{\mathrm{a}}$ & $2.53 \pm 0.55^{\mathrm{a}}$ & $2.93 \pm 0.68^{\mathrm{a}}$ & $3.26 \pm 0.79^{\mathrm{a}} 3.37 \pm 0.78$ \\
\hline D6 (ㅇ) & $0.69 \pm 0.11^{b}$ & $0.96 \pm 0.21^{\mathrm{b}} 1.45 \pm 0.66^{\mathrm{b}}$ & $1.78 \pm 0.66^{\mathrm{b}}$ & $1.87 \pm 0.61^{b}$ & $2.06 \pm 0.56^{\mathrm{b}}$ & $2.38 \pm 0.79^{b}$ & $2.61 \pm 0.73^{\mathrm{b}} 2.83 \pm 0.62^{\mathrm{b}}$ \\
\hline D7 (ठ゚) & $0.48 \pm 0.11^{\mathrm{a}}$ & $0.74 \pm 0.20^{\mathrm{a}} 1.43 \pm 0.41^{\mathrm{a}}$ & $1.60 \pm 0.49^{\mathrm{a}}$ & $1.70 \pm 0.44^{\mathrm{a}}$ & $1.99 \pm 0.55^{\mathrm{a}}$ & $2.44 \pm 0.53^{\mathrm{a}}$ & $2.85 \pm 0.74^{\mathrm{a}} 2.95 \pm 0.64^{\mathrm{a}}$ \\
\hline D7 (q) & $0.48 \pm 0.08^{\mathrm{b}}$ & $0.74 \pm 0.25^{\mathrm{b}} 1.25 \pm 0.52^{\mathrm{b}}$ & $1.32 \pm 0.46^{\mathrm{b}}$ & $1.42 \pm 0.47^{b}$ & $1.59 \pm 0.50^{\mathrm{b}}$ & $1.74 \pm 0.76^{\mathrm{b}}$ & $2.07 \pm 0.51^{\mathrm{b}} 2.21 \pm 0.87^{\mathrm{b}}$ \\
\hline
\end{tabular}

*For abbreviations see Table 2. The sample numbers of males and females are 30 and 30, respectively. $P<0.05$.

Table 6. Results of Student's $\boldsymbol{t}$-test for differences in A1-A21 fin distance of anal fin between male ( $\overbrace{}^{\Uparrow})$ and female ( $q$ ) of marine medaka, Oryzias dancena by days after hatched*

\begin{tabular}{|c|c|c|c|c|c|c|c|c|c|}
\hline $\begin{array}{c}\text { Days after } \\
\text { hatched }\end{array}$ & 32 & 40 & 70 & 110 & 150 & 190 & 230 & 270 & 330 \\
\hline A1 $\left(ठ^{\Uparrow}\right)$ & $0.81 \pm 0.11^{\mathrm{a}}$ & $0.97 \pm 0.21^{\mathrm{a}}$ & $1.48 \pm 0.57^{\mathrm{a}}$ & $1.66 \pm 0.70^{\mathrm{a}}$ & $1.75 \pm 0.48^{\mathrm{a}}$ & $1.96 \pm 0.84^{\mathrm{a}}$ & $2.28 \pm 0.85^{\mathrm{a}}$ & $2.53 \pm 0.78^{a}$ & $2.54 \pm 0.91^{\mathrm{a}}$ \\
\hline $\mathrm{A} 1($ ( $)$ & $0.74 \pm 0.15^{\mathrm{b}}$ & $0.83 \pm 0.22^{b}$ & $1.25 \pm 0.58^{\mathrm{b}}$ & $1.50 \pm 0.50^{\mathrm{b}}$ & $1.54 \pm 0.58^{\mathrm{b}}$ & $1.75 \pm 0.86^{\mathrm{b}}$ & $2.11 \pm 0.91^{\mathrm{b}}$ & $2.28 \pm 0.85^{b}$ & $2.29 \pm 0.82^{\mathrm{b}}$ \\
\hline A2 $\left(ठ^{\lambda}\right)$ & $1.50 \pm 0.28^{\mathrm{a}}$ & $1.59 \pm 0.25^{\mathrm{a}}$ & $2.29 \pm 0.59^{\mathrm{a}}$ & $2.60 \pm 0.55^{\mathrm{a}}$ & $2.78 \pm 0.84^{\mathrm{a}}$ & $3.14 \pm 0.83^{\mathrm{a}}$ & $3.46 \pm 0.87^{\mathrm{a}}$ & $3.74 \pm 0.77^{\mathrm{a}}$ & $3.80 \pm 0.75^{\mathrm{a}}$ \\
\hline $\mathrm{A} 2\left(\begin{array}{l}+ \\
+\end{array}\right.$ & $1.33 \pm 0.34^{\mathrm{b}}$ & $1.41 \pm 0.54^{\mathrm{b}}$ & $1.97 \pm 0.58^{\mathrm{b}}$ & $2.37 \pm 0.54^{\mathrm{b}}$ & $2.48 \pm 0.87^{\mathrm{b}}$ & $2.71 \pm 0.81^{\mathrm{b}}$ & $2.95 \pm 0.83^{b}$ & $3.20 \pm 0.89^{b}$ & $3.22 \pm 0.79^{b}$ \\
\hline A3 $(ठ)$ & $1.63 \pm 0.31^{\mathrm{a}}$ & $1.75 \pm 0.51^{\mathrm{a}}$ & $2.53 \pm 0.52^{\mathrm{a}}$ & $2.85 \pm 0.74^{\mathrm{a}}$ & $3.02 \pm 0.89^{\mathrm{a}}$ & $3.50 \pm 0.84^{\mathrm{a}}$ & $4.04 \pm 0.85^{\mathrm{a}}$ & $4.74 \pm 0.97^{\mathrm{a}}$ & $4.81 \pm 0.77^{\mathrm{a}}$ \\
\hline $\mathrm{A} 3($ ( $)$ & $1.40 \pm 0.45^{\mathrm{b}}$ & $1.50 \pm 0.43^{b}$ & $2.08 \pm 0.61^{\mathrm{b}}$ & $2.51 \pm 0.48^{\mathrm{b}}$ & $2.63 \pm 0.90^{b}$ & $2.89 \pm 0.89^{b}$ & $3.54 \pm 0.77^{\mathrm{b}}$ & $3.82 \pm 0.91^{\mathrm{b}}$ & $3.85 \pm 0.85^{\mathrm{b}}$ \\
\hline $\mathrm{A} 4\left(ठ^{\lambda}\right)$ & $1.64 \pm 0.35^{\mathrm{a}}$ & $1.80 \pm 0.39^{\mathrm{a}}$ & $2.71 \pm 0.62^{\mathrm{a}}$ & $3.02 \pm 0.82^{\mathrm{a}}$ & $3.29 \pm 0.99^{\mathrm{a}}$ & $3.74 \pm 0.94^{\mathrm{a}}$ & $4.00 \pm 0.76^{\mathrm{a}}$ & $4.22 \pm 0.99^{\mathrm{a}}$ & $4.39 \pm 0.91^{\mathrm{a}}$ \\
\hline A4 (q) & $1.37 \pm 0.42^{\mathrm{a}}$ & $1.57 \pm 0.34^{\mathrm{b}}$ & $2.16 \pm 0.63^{\mathrm{b}}$ & $2.58 \pm 0.58^{\mathrm{b}}$ & $2.72 \pm 0.81^{\mathrm{b}}$ & $3.05 \pm 0.99^{\mathrm{b}}$ & $3.65 \pm 0.94^{\mathrm{b}}$ & $3.88 \pm 0.75^{\mathrm{b}}$ & $3.92 \pm 0.93^{b}$ \\
\hline $\mathrm{A} 5(ठ)$ & $1.72 \pm 0.47^{\mathrm{a}}$ & $1.91 \pm 0.33^{\mathrm{a}}$ & $2.93 \pm 0.68^{\mathrm{a}}$ & $3.34 \pm 0.87^{\mathrm{a}}$ & $3.66 \pm 0.98^{\mathrm{a}}$ & $4.08 \pm 0.90^{\mathrm{a}}$ & $4.86 \pm 0.78^{\mathrm{a}}$ & $5.72 \pm 0.95^{\mathrm{a}}$ & $5.80 \pm 0.97^{\mathrm{a}}$ \\
\hline A5 (q) & $1.38 \pm 0.52^{\mathrm{b}}$ & $1.57 \pm 0.45^{\mathrm{ba}}$ & $2.19 \pm 0.66^{\mathrm{b}}$ & $2.60 \pm 0.48^{b}$ & $2.76 \pm 0.88^{b}$ & $3.03 \pm 0.91^{\mathrm{b}}$ & $3.64 \pm 0.78^{b}$ & $3.89 \pm 0.93^{b}$ & $3.97 \pm 0.90^{\mathrm{b}}$ \\
\hline A6 $\left(ठ^{\lambda}\right)$ & $1.55 \pm 0.53^{\mathrm{a}}$ & $1.96 \pm 0.41^{\mathrm{a}}$ & $3.05 \pm 0.69^{\mathrm{a}}$ & $3.74 \pm 0.87^{\mathrm{a}}$ & $4.06 \pm 0.99^{\mathrm{a}}$ & $4.59 \pm 0.97^{\mathrm{a}}$ & $5.55 \pm 0.95^{\mathrm{a}}$ & $6.53 \pm 0.94^{\mathrm{a}}$ & $6.70 \pm 0.87^{\mathrm{a}}$ \\
\hline A6 (P) & $1.33 \pm 0.48^{\mathrm{b}}$ & $1.52 \pm 0.39^{b}$ & $2.12 \pm 0.61^{\mathrm{b}}$ & $2.58 \pm 0.88^{b}$ & $2.65 \pm 0.91^{\mathrm{b}}$ & $3.01 \pm 0.84^{b}$ & $3.51 \pm 0.75^{b}$ & $4.32 \pm 0.78^{b}$ & $4.50 \pm 0.71^{\mathrm{b}}$ \\
\hline
\end{tabular}




\section{Table 6. Continued}

\begin{tabular}{|c|c|c|c|c|c|c|c|c|c|}
\hline $\begin{array}{c}\text { Days after } \\
\text { hatched }\end{array}$ & 32 & 40 & 70 & 110 & 150 & 190 & 230 & 270 & 330 \\
\hline A7 $\left(ठ^{\lambda}\right)$ & $1.55 \pm 0.39^{\mathrm{a}}$ & $1.85 \pm 0.28^{\mathrm{a}}$ & $3.32 \pm 0.65^{\mathrm{a}}$ & $4.17 \pm 0.77^{\mathrm{a}}$ & $4.47 \pm 0.93^{\mathrm{a}}$ & $5.02 \pm 0.87^{\mathrm{a}}$ & $6.33 \pm 0.97^{\mathrm{a}}$ & $7.65 \pm 0.87^{\mathrm{a}}$ & $7.80 \pm 0.91^{\mathrm{a}}$ \\
\hline A7 (우) & $1.25 \pm 0.54^{\mathrm{b}}$ & $1.38 \pm 0.39^{b}$ & $1.97 \pm 0.64^{\mathrm{b}}$ & $2.40 \pm 0.66^{\mathrm{b}}$ & $2.53 \pm 0.92^{b}$ & $2.79 \pm 0.89^{b}$ & $3.48 \pm 0.78^{\mathrm{b}}$ & $3.92 \pm 0.88^{b}$ & $4.00 \pm 0.83^{b}$ \\
\hline $\mathrm{A} 8\left(ठ^{\lambda}\right)$ & $1.53 \pm 0.24^{\mathrm{a}}$ & $1.80 \pm 0.37^{\mathrm{a}}$ & $3.37 \pm 0.48^{\mathrm{a}}$ & $4.00 \pm 0.64^{\mathrm{a}}$ & $4.90 \pm 0.94^{\mathrm{a}}$ & $5.85 \pm 0.98^{\mathrm{a}}$ & $7.40 \pm 0.88^{\mathrm{a}}$ & $7.61 \pm 0.91^{\mathrm{a}}$ & $7.88 \pm 0.78^{\mathrm{a}}$ \\
\hline A8 (ㅇ) & $1.17 \pm 0.35^{\mathrm{b}}$ & $1.32 \pm 0.34^{\mathrm{b}}$ & $1.82 \pm 0.58^{\mathrm{b}}$ & $2.26 \pm 0.62^{b}$ & $2.39 \pm 0.96^{\mathrm{b}}$ & $2.70 \pm 0.91^{\mathrm{b}}$ & $3.24 \pm 0.85^{\mathrm{b}}$ & $3.75 \pm 0.81^{b}$ & $3.86 \pm 0.86^{\mathrm{b}}$ \\
\hline A9 $\left(\delta^{\lambda}\right)$ & $1.45 \pm 0.30^{\mathrm{a}}$ & $1.73 \pm 0.54^{\mathrm{a}}$ & $2.97 \pm 0.55^{\mathrm{a}}$ & $3.53 \pm 0.67^{\mathrm{a}}$ & $3.94 \pm 0.91^{\mathrm{a}}$ & $4.94 \pm 0.90^{\mathrm{a}}$ & $6.38 \pm 0.97^{\mathrm{a}}$ & $8.03 \pm 0.83^{\mathrm{a}}$ & $8.19 \pm 0.94^{\mathrm{a}}$ \\
\hline A9 (ㅇ) & $1.12 \pm 0.33^{b}$ & $1.21 \pm 0.35^{\mathrm{b}}$ & $1.73 \pm 0.58^{b}$ & $2.08 \pm 0.62^{b}$ & $2.26 \pm 0.87^{b}$ & $2.57 \pm 0.80^{\mathrm{b}}$ & $3.20 \pm 0.86^{\mathrm{b}}$ & $3.51 \pm 0.89^{b}$ & $3.59 \pm 0.95^{\mathrm{b}}$ \\
\hline $\operatorname{A10}\left(\delta^{\lambda}\right)$ & $1.37 \pm 0.28^{\mathrm{a}}$ & $1.64 \pm 0.60^{\mathrm{a}}$ & $2.48 \pm 0.59^{\mathrm{a}}$ & $3.18 \pm 0.63^{\mathrm{a}}$ & $3.56 \pm 0.88^{\mathrm{a}}$ & $4.29 \pm 0.87^{\mathrm{a}}$ & $5.94 \pm 0.78^{\mathrm{a}}$ & $6.93 \pm 0.98^{\mathrm{a}}$ & $7.00 \pm 0.88^{\mathrm{a}}$ \\
\hline $\mathrm{A} 10(q)$ & $1.11 \pm 0.38^{\mathrm{b}}$ & $1.19 \pm 0.38^{\mathrm{b}}$ & $1.69 \pm 0.51^{\mathrm{b}}$ & $2.06 \pm 0.66^{\mathrm{b}}$ & $2.25 \pm 0.97^{\mathrm{b}}$ & $2.50 \pm 0.94^{\mathrm{b}}$ & $3.11 \pm 0.88^{b}$ & $3.35 \pm 0.78^{b}$ & $3.50 \pm 0.84^{\mathrm{b}}$ \\
\hline $\operatorname{A} 11(ふ)$ & $1.30 \pm 0.34^{\mathrm{a}}$ & $1.51 \pm 0.43^{\mathrm{a}}$ & $2.32 \pm 0.58^{\mathrm{a}}$ & $2.76 \pm 0.58^{\mathrm{a}}$ & $3.14 \pm 0.51^{\mathrm{a}}$ & & & & \\
\hline A11 (q) & $1.07 \pm 0.44^{\mathrm{b}}$ & $1.18 \pm 0.33^{\mathrm{b}}$ & $1.71 \pm 0.65^{\mathrm{b}}$ & $2.14 \pm 0.64^{b}$ & $2.23 \pm 0.68^{\mathrm{b}}$ & $2.44 \pm 0.77^{b}$ & $2.89 \pm 0.68^{b}$ & $3.14 \pm 0.96^{\mathrm{b}}$ & $3.34 \pm 0.85^{\mathrm{b}}$ \\
\hline $\mathrm{A} 12\left(ठ^{\Uparrow}\right)$ & $1.26 \pm 0.42^{\mathrm{a}}$ & $1.46 \pm 0.48^{\mathrm{a}}$ & $2.17 \pm 0.54^{\mathrm{a}}$ & $2.51 \pm 0.68^{\mathrm{a}}$ & $2.85 \pm 0.81^{\mathrm{a}}$ & $3.45 \pm 0.68^{\mathrm{a}}$ & $4.94 \pm 0.87^{\mathrm{a}}$ & $6.45 \pm 0.98^{a}$ & $6.67 \pm 0.98^{\mathrm{a}}$ \\
\hline $\mathrm{A} 12(q)$ & $1.05 \pm 0.32^{\mathrm{b}}$ & $1.18 \pm 0.32^{\mathrm{b}}$ & $1.68 \pm 0.52^{b}$ & $2.01 \pm 0.71^{b}$ & $2.15 \pm 0.46^{b}$ & $2.41 \pm 0.78^{\mathrm{b}}$ & $2.83 \pm 0.54^{b}$ & $3.17 \pm 0.99^{b}$ & $3.44 \pm 0.66^{\mathrm{b}}$ \\
\hline $\mathrm{A} 13\left(ठ^{\Uparrow}\right)$ & $1.22 \pm 0.25^{\mathrm{a}}$ & $1.40 \pm 0.31^{\mathrm{a}}$ & $2.09 \pm 0.61^{\mathrm{a}}$ & $2.41 \pm 0.64^{\mathrm{a}}$ & $2.70 \pm 0.71^{\mathrm{a}}$ & $3.21 \pm 0.88^{\mathrm{a}}$ & $3.82 \pm 0.89^{\mathrm{a}}$ & $4.54 \pm 0.97^{\mathrm{a}}$ & $4.60 \pm 0.77^{\mathrm{a}}$ \\
\hline $\mathrm{A} 13$ (ㅇ) & $1.07 \pm 0.21^{\mathrm{b}}$ & $1.14 \pm 0.33^{\mathrm{b}}$ & $1.66 \pm 0.56^{\mathrm{b}}$ & $1.95 \pm 0.61^{b}$ & $2.08 \pm 0.65^{\mathrm{b}}$ & $2.38 \pm 0.87^{\mathrm{b}}$ & $2.79 \pm 0.62^{b}$ & $3.03 \pm 0.89^{b}$ & $3.45 \pm 0.57^{\mathrm{b}}$ \\
\hline 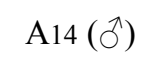 & $1.18 \pm 0.39^{\mathrm{a}}$ & $1.35 \pm 0.36^{\mathrm{a}}$ & $2.10 \pm 0.68^{a}$ & $2.38 \pm 0.51^{\mathrm{a}}$ & $2.64 \pm 0.66^{\mathrm{a}}$ & $3.09 \pm 0.87^{\mathrm{a}}$ & $3.46 \pm 0.94^{\mathrm{a}}$ & $3.88 \pm 0.87^{\mathrm{a}}$ & $3.92 \pm 0.68^{\mathrm{a}}$ \\
\hline $\mathrm{A} 14$ (q) & $1.04 \pm 0.34^{\mathrm{b}}$ & $1.16 \pm 0.38^{b}$ & & & & & & & \\
\hline $\operatorname{A} 15\left(ठ^{\Uparrow}\right)$ & $1.14 \pm 0.31^{\mathrm{a}}$ & $1.31 \pm 0.37^{\mathrm{a}}$ & $1.98 \pm 0.57^{\mathrm{a}}$ & $2.37 \pm 0.54^{\mathrm{a}}$ & $2.58 \pm 0.67^{\mathrm{a}}$ & $3.00 \pm 0.68^{\mathrm{a}}$ & $3.40 \pm 0.99^{\mathrm{a}}$ & $3.61 \pm 0.94^{\mathrm{a}}$ & $3.78 \pm 0.69^{\mathrm{a}}$ \\
\hline A15 (ㅇ) & $1.05 \pm 0.28^{\mathrm{b}}$ & $1.13 \pm 0.34^{b}$ & $1.60 \pm 0.61^{\mathrm{b}}$ & $1.89 \pm 0.68^{b}$ & & $2.22 \pm 0.77^{b}$ & $2.43 \pm 0.54^{\mathrm{b}}$ & $2.71 \pm 0.94^{b}$ & $2.80 \pm 0.96^{\mathrm{b}}$ \\
\hline $\operatorname{A} 16\left(\delta^{\lambda}\right)$ & $1.09 \pm 0.29^{\mathrm{a}}$ & $1.27 \pm 0.33^{\mathrm{a}}$ & $2.00 \pm 0.53^{\mathrm{a}}$ & $2.24 \pm 0.48^{\mathrm{a}}$ & $2.56 \pm 0.60^{\mathrm{a}}$ & $2.89 \pm 0.69^{\mathrm{a}}$ & & $3.80 \pm 0.64^{\mathrm{a}}$ & $3.85 \pm 0.91^{\mathrm{a}}$ \\
\hline A16 (q) & $1.05 \pm 0.36^{\mathrm{b}}$ & $1.10 \pm 0.41^{\mathrm{b}}$ & $1.58 \pm 0.61^{\mathrm{b}}$ & $1.90 \pm 0.69^{b}$ & $1.96 \pm 0.58^{b}$ & $2.15 \pm 0.72^{b}$ & $2.41 \pm 0.62^{b}$ & $2.65 \pm 0.68^{b}$ & $2.70 \pm 0.87^{\mathrm{b}}$ \\
\hline $\operatorname{A} 17(ð)$ & $1.06 \pm 0.34^{\mathrm{a}}$ & $1.22 \pm 0.31^{\mathrm{a}}$ & $1.96 \pm 0.54^{\mathrm{a}}$ & $2.35 \pm 0.77^{\mathrm{a}}$ & $2.62 \pm 0.59^{\mathrm{a}}$ & $2.99 \pm 0.68^{\mathrm{a}}$ & $3.43 \pm 0.87^{\mathrm{a}}$ & $3.76 \pm 0.87^{\mathrm{a}}$ & $3.80 \pm 0.99^{\mathrm{a}}$ \\
\hline $\mathrm{A} 17$ (ㅇ) & $1.00 \pm 0.28^{\mathrm{b}}$ & $1.08 \pm 0.31^{\mathrm{b}}$ & $1.59 \pm 0.55^{\mathrm{b}}$ & $1.87 \pm 0.72^{\mathrm{b}}$ & $1.92 \pm 0.64^{b}$ & $2.08 \pm 0.71^{\mathrm{b}}$ & $2.32 \pm 0.62^{b}$ & $2.65 \pm 0.89^{b}$ & $2.70 \pm 0.88^{b}$ \\
\hline $\operatorname{A} 18(ठ)$ & $1.05 \pm 0.34^{\mathrm{a}}$ & $1.14 \pm 0.42^{\mathrm{a}}$ & $1.86 \pm 0.61^{\mathrm{a}}$ & $2.36 \pm 0.70^{\mathrm{a}}$ & $2.52 \pm 0.69^{a}$ & $2.83 \pm 0.78^{\mathrm{a}}$ & $3.34 \pm 0.88^{\mathrm{a}}$ & $3.60 \pm 0.94^{\mathrm{a}}$ & $3.62 \pm 0.99^{\mathrm{a}}$ \\
\hline A18 (ㅇ) & $0.96 \pm 0.29^{\mathrm{b}}$ & $1.04 \pm 0.31^{\mathrm{b}}$ & $1.48 \pm 0.50^{\mathrm{b}}$ & $1.75 \pm 0.48^{\mathrm{b}}$ & $1.85 \pm 0.68^{\mathrm{b}}$ & $2.03 \pm 0.86^{\mathrm{b}}$ & $2.34 \pm 0.64^{\mathrm{b}}$ & $2.70 \pm 0.67^{\mathrm{b}}$ & $2.75 \pm 0.87^{\mathrm{b}}$ \\
\hline A19 (ठ) & $0.94 \pm 0.33^{\mathrm{a}}$ & $1.05 \pm 0.29^{\mathrm{a}}$ & $1.74 \pm 0.56^{\mathrm{a}}$ & $2.19 \pm 0.65^{\mathrm{a}}$ & $2.33 \pm 0.77^{\mathrm{a}}$ & $2.60 \pm 0.61^{\mathrm{a}}$ & $3.23 \pm 0.69^{\mathrm{a}}$ & $3.50 \pm 0.74^{\mathrm{a}}$ & $3.51 \pm 0.91^{\mathrm{a}}$ \\
\hline $\mathrm{A} 19$ (ㅇ) & $0.83 \pm 0.25^{\mathrm{b}}$ & $0.91 \pm 0.27 b$ & $1.35 \pm 0.50^{\mathrm{b}}$ & $1.63 \pm 0.52^{b}$ & $1.71 \pm 0.57^{b}$ & $1.86 \pm 0.69^{b}$ & $2.27 \pm 0.65^{\mathrm{b}}$ & $2.55 \pm 0.78^{b}$ & $2.61 \pm 0.78^{\mathrm{b}}$ \\
\hline A20 $(\hat{O})$ & $0.81 \pm 0.35^{\mathrm{a}}$ & $0.86 \pm 0.23 \mathrm{a}$ & $1.44 \pm 0.43^{\mathrm{a}}$ & $1.77 \pm 0.59^{\mathrm{a}}$ & $1.91 \pm 0.67^{\mathrm{a}}$ & $2.16 \pm 0.62^{\mathrm{a}}$ & $2.81 \pm 0.67^{\mathrm{a}}$ & $3.34 \pm 0.67^{\mathrm{a}}$ & $3.35 \pm 0.92^{\mathrm{a}}$ \\
\hline A20 (q) & $0.80 \pm 0.33^{\mathrm{b}}$ & $0.86 \pm 0.28 \mathrm{~b}$ & $1.19 \pm 0.21^{b}$ & $1.47 \pm 0.42^{b}$ & $1.53 \pm 0.69^{b}$ & $1.73 \pm 0.74^{\mathrm{b}}$ & $1.99 \pm 0.77^{\mathrm{b}}$ & $2.16 \pm 0.98^{b}$ & $2.20 \pm 0.95^{\mathrm{b}}$ \\
\hline $\mathrm{A} 21\left(\delta^{\lambda}\right)$ & $0.58 \pm 0.22^{\mathrm{a}}$ & $0.82 \pm 0.34 \mathrm{a}$ & $1.25 \pm 0.48^{\mathrm{a}}$ & $1.51 \pm 0.68^{\mathrm{a}}$ & $1.69 \pm 0.61^{\mathrm{a}}$ & $2.02 \pm 0.67^{\mathrm{a}}$ & $2.59 \pm 0.69^{\mathrm{a}}$ & $2.87 \pm 0.98^{\mathrm{a}}$ & $2.90 \pm 0.94^{\mathrm{a}}$ \\
\hline $\mathrm{A} 21$ ( $(+)$ & $0.53 \pm 0.20^{b}$ & $0.69 \pm 0.18 b$ & $1.03 \pm 0.45^{\mathrm{b}}$ & $1.26 \pm 0.45^{\mathrm{b}}$ & $1.29 \pm 0.62^{b}$ & $1.45 \pm 0.78^{\mathrm{b}}$ & $1.68 \pm 0.59^{\mathrm{b}}$ & $1.84 \pm 0.77^{\mathrm{b}}$ & $1.85 \pm 0.68^{\mathrm{b}}$ \\
\hline
\end{tabular}

${ }^{*}$ For abbreviations see Table 2 . The sample numbers of males and females are 30 and 30, respectively. $P<0.05$. 
Table 7. Results of Student's $t$-test for differences in A1-A21 separated fin distance of anal fin between male ( $\overbrace{}^{\Uparrow}$ ) and female ( + ) of marine medaka, Oryzias dancena by days after hatched*

\begin{tabular}{|c|c|c|c|c|c|c|c|}
\hline $\begin{array}{l}\text { Days after } \\
\text { hatched }\end{array}$ & 60 & 70 & 90 & 130 & 190 & 250 & 330 \\
\hline $\mathrm{A} 1\left(ठ^{\Uparrow}\right)$ & $\mathrm{N}$ & $\mathrm{N}$ & $\mathrm{N}$ & $\mathrm{N}$ & $\mathrm{N}$ & $\mathrm{N}$ & $0.03 \pm 0.11^{\mathrm{a}}$ \\
\hline $\mathrm{A} 1(q)$ & $\mathrm{N}$ & $\mathrm{N}$ & $\mathrm{N}$ & $\mathrm{N}$ & $\mathrm{N}$ & $\mathrm{N}$ & $0.01 \pm 0.11^{\mathrm{a}}$ \\
\hline A2 $(ठ)$ & $\mathrm{N}$ & $\mathrm{N}$ & $\mathrm{N}$ & $\mathrm{N}$ & $\mathrm{N}$ & $\mathrm{N}$ & $0.03 \pm 0.01^{\mathrm{a}}$ \\
\hline A2 $(q)$ & $\mathrm{N}$ & $\mathrm{N}$ & $\mathrm{N}$ & $\mathrm{N}$ & $\mathrm{N}$ & $\mathrm{N}$ & $0.01 \pm 0.00^{\mathrm{a}}$ \\
\hline A3 $(ठ)$ & $\mathrm{N}$ & $\mathrm{N}$ & $\mathrm{N}$ & $\mathrm{N}$ & $\mathrm{N}$ & $0.60 \pm 0.09^{\mathrm{a}}$ & $0.73 \pm 0.11^{\mathrm{a}}$ \\
\hline A3 $($ P) & $\mathrm{N}$ & $0.13 \pm 0.03$ & $0.25 \pm 0.01$ & $0.32 \pm 0.01$ & $0.50 \pm 0.11$ & $0.72 \pm 0.15^{b}$ & $0.75 \pm 0.13^{\mathrm{a}}$ \\
\hline A4 $\left(ठ^{\lambda}\right)$ & $\mathrm{N}$ & $\mathrm{N}$ & $\mathrm{N}$ & $\mathrm{N}$ & $\mathrm{N}$ & $0.86 \pm 0.17^{\mathrm{a}}$ & $0.98 \pm 0.22^{\mathrm{a}}$ \\
\hline A4 $(q)$ & $\mathrm{N}$ & $0.16 \pm 0.01$ & $0.37 \pm 0.02$ & $0.39 \pm 0.02$ & $0.63 \pm 0.12$ & $0.77 \pm 0.16^{\mathrm{b}}$ & $0.87 \pm 0.20^{\mathrm{b}}$ \\
\hline A5 $\left(ठ^{\Uparrow}\right)$ & $\mathrm{N}$ & $\mathrm{N}$ & $\mathrm{N}$ & $\mathrm{N}$ & $\mathrm{N}$ & $\mathrm{N}$ & $\mathrm{N}$ \\
\hline A5 $(q)$ & $0.19 \pm 0.05$ & $0.28 \pm 0.07$ & $0.39 \pm 0.03$ & $0.48 \pm 0.06$ & $0.64 \pm 0.13$ & $0.83 \pm 0.17$ & $1.12 \pm 0.15$ \\
\hline A6 $\left(ठ^{\lambda}\right)$ & $\mathrm{N}$ & $\mathrm{N}$ & $\mathrm{N}$ & $\mathrm{N}$ & $\mathrm{N}$ & $\mathrm{N}$ & $\mathrm{N}$ \\
\hline A6 (ㅇ) & $0.24 \pm 0.08$ & $0.33 \pm 0.02$ & $0.36 \pm 0.05$ & $0.51 \pm 0.08$ & $0.68 \pm 0.09$ & $0.88 \pm 0.19$ & $1.20 \pm 0.19$ \\
\hline A7 $(ठ)$ & $\mathrm{N}$ & $\mathrm{N}$ & $\mathrm{N}$ & $\mathrm{N}$ & $\mathrm{N}$ & $\mathrm{N}$ & $\mathrm{N}$ \\
\hline A7 ( $(+)$ & $0.22 \pm 0.09$ & $0.23 \pm 0.06$ & $0.23 \pm 0.04$ & $0.46 \pm 0.12$ & $0.62 \pm 0.08$ & $0.76 \pm 0.21$ & $1.03 \pm 0.16$ \\
\hline A8 $\left(ठ^{\Uparrow}\right)$ & $\mathrm{N}$ & $\mathrm{N}$ & $\mathrm{N}$ & $\mathrm{N}$ & $\mathrm{N}$ & $\mathrm{N}$ & $\mathrm{N}$ \\
\hline A8 (q) & $0.19 \pm 0.05$ & $0.19 \pm 0.05$ & $0.25 \pm 0.06$ & $0.38 \pm 0.03$ & $0.53 \pm 0.11$ & $0.71 \pm 0.20$ & $1.10 \pm 0.18$ \\
\hline A9 (ठ) & $\mathrm{N}$ & $\mathrm{N}$ & $\mathrm{N}$ & $\mathrm{N}$ & $\mathrm{N}$ & $\mathrm{N}$ & $\mathrm{N}$ \\
\hline A9 ( $(+)$ & $0.18 \pm 0.05$ & $0.22 \pm 0.12$ & $0.27 \pm 0.08$ & $0.43 \pm 0.06$ & $0.57 \pm 0.14$ & $0.78 \pm 0.19$ & $0.99 \pm 0.22$ \\
\hline $\mathrm{A} 10\left(ठ^{\Uparrow}\right)$ & $\mathrm{N}$ & $\mathrm{N}$ & $\mathrm{N}$ & $\mathrm{N}$ & $\mathrm{N}$ & $\mathrm{N}$ & $\mathrm{N}$ \\
\hline $\mathrm{A} 10(+)$ & $0.22 \pm 0.04$ & $0.24 \pm 0.10$ & $0.31 \pm 0.01$ & $0.41 \pm 0.08$ & $0.58 \pm 0.10$ & $0.70 \pm 0.13$ & $0.95 \pm 0.23$ \\
\hline $\mathrm{A} 11\left(ठ^{\Uparrow}\right)$ & $\mathrm{N}$ & $\mathrm{N}$ & $\mathrm{N}$ & $\mathrm{N}$ & $\mathrm{N}$ & $\mathrm{N}$ & $\mathrm{N}$ \\
\hline A11 (q) & $0.21 \pm 0.11$ & $0.27 \pm 0.05$ & $0.27 \pm 0.11$ & $0.48 \pm 0.11$ & $0.54 \pm 0.19$ & $0.78 \pm 0.12$ & $1.01 \pm 0.17$ \\
\hline $\mathrm{A} 12\left(ठ^{\Uparrow}\right)$ & $\mathrm{N}$ & $\mathrm{N}$ & $\mathrm{N}$ & $\mathrm{N}$ & $\mathrm{N}$ & $\mathrm{N}$ & $\mathrm{N}$ \\
\hline $\mathrm{A} 12($ O $)$ & $0.25 \pm 0.05$ & $0.25 \pm 0.09$ & $0.26 \pm 0.09$ & $0.46 \pm 0.11$ & $0.64 \pm 0.18$ & $0.80 \pm 0.11$ & $1.03 \pm 0.17$ \\
\hline $\mathrm{A} 13\left(ठ^{\Uparrow}\right)$ & $\mathrm{N}$ & $\mathrm{N}$ & $\mathrm{N}$ & $\mathrm{N}$ & $\mathrm{N}$ & $\mathrm{N}$ & $\mathrm{N}$ \\
\hline $\mathrm{A} 13(9)$ & $0.19 \pm 0.07$ & $0.24 \pm 0.11$ & $0.28 \pm 0.08$ & $0.42 \pm 0.11$ & $0.61 \pm 0.11$ & $0.72 \pm 0.18$ & $1.02 \pm 0.19$ \\
\hline $\mathrm{A} 14\left(ठ^{\Uparrow}\right)$ & $\mathrm{N}$ & $\mathrm{N}$ & $\mathrm{N}$ & $\mathrm{N}$ & $\mathrm{N}$ & $\mathrm{N}$ & $\mathrm{N}$ \\
\hline $\mathrm{A} 14(q)$ & $0.21 \pm 0.09$ & $0.22 \pm 0.07$ & $0.29 \pm 0.06$ & $0.39 \pm 0.13$ & $0.58 \pm 0.18$ & $0.79 \pm 0.17$ & $1.37 \pm 0.17$ \\
\hline $\mathrm{A} 15\left(ठ^{\Uparrow}\right)$ & $\mathrm{N}$ & $\mathrm{N}$ & $\mathrm{N}$ & $\mathrm{N}$ & $\mathrm{N}$ & $\mathrm{N}$ & $\mathrm{N}$ \\
\hline A15 (†) & $0.20 \pm 0.05$ & $0.25 \pm 0.10$ & $0.26 \pm 0.07$ & $0.42 \pm 0.12$ & $0.62 \pm 0.17$ & $0.74 \pm 0.17$ & $1.10 \pm 0.18$ \\
\hline $\mathrm{A} 16\left(ठ^{\Uparrow}\right)$ & $\mathrm{N}$ & $\mathrm{N}$ & $\mathrm{N}$ & $\mathrm{N}$ & $\mathrm{N}$ & $\mathrm{N}$ & $\mathrm{N}$ \\
\hline $\mathrm{A} 16(q)$ & $0.20 \pm 0.06$ & $0.24 \pm 0.05$ & $0.31 \pm 0.12$ & $0.44 \pm 0.11$ & $0.64 \pm 0.16$ & $0.81 \pm 0.18$ & $1.09 \pm 0.19$ \\
\hline A17 (ठ઼) & $\mathrm{N}$ & $\mathrm{N}$ & $\mathrm{N}$ & $\mathrm{N}$ & $\mathrm{N}$ & $\mathrm{N}$ & $\mathrm{N}$ \\
\hline A17 (q) & $0.18 \pm 0.07$ & $0.30 \pm 0.08$ & $0.31 \pm 0.10$ & $0.50 \pm 0.10$ & $0.65 \pm 0.13$ & $0.86 \pm 0.16$ & $1.03 \pm 0.17$ \\
\hline
\end{tabular}


Table 7. Continued

\begin{tabular}{|c|c|c|c|c|c|c|c|}
\hline $\begin{array}{l}\text { Days after } \\
\text { hatched }\end{array}$ & 60 & 70 & 90 & 130 & 190 & 250 & 330 \\
\hline A18 (ठ̊) & $\mathrm{N}$ & $\mathrm{N}$ & $\mathrm{N}$ & $\mathrm{N}$ & $\mathrm{N}$ & $\mathrm{N}$ & $\mathrm{N}$ \\
\hline $\mathrm{A} 18(+)$ & $0.24 \pm 0.04$ & $0.37 \pm 0.07$ & $0.38 \pm 0.09$ & $0.55 \pm 0.13$ & $0.70 \pm 0.19$ & $0.86 \pm 0.11$ & $1.44 \pm 0.11$ \\
\hline A19 (ठ) & $\mathrm{N}$ & $\mathrm{N}$ & $\mathrm{N}$ & $\mathrm{N}$ & $0.92 \pm 0.19 a$ & $1.39 \pm 0.21 \mathrm{a}$ & $1.41 \pm 0.27 \mathrm{a}$ \\
\hline A19 (q) & $0.32 \pm 0.01$ & $0.36 \pm 0.06$ & $0.37 \pm 0.07$ & $0.56 \pm 0.12$ & $0.74 \pm 0.14 \mathrm{a}$ & $0.95 \pm 0.19 b$ & $1.20 \pm 0.22 \mathrm{~b}$ \\
\hline A20 (ठ) & $\mathrm{N}$ & $\mathrm{N}$ & $\mathrm{N}$ & $\mathrm{N}$ & $0.91 \pm 0.14 \mathrm{a}$ & $1.28 \pm 0.22 \mathrm{a}$ & $1.56 \pm 0.28 \mathrm{a}$ \\
\hline A20 (q) & $0.37 \pm 0.09$ & $0.44 \pm 0.12$ & $0.48 \pm 0.11$ & $0.67 \pm 0.18$ & $0.81 \pm 0.12 b$ & $1.04 \pm 0.12 b$ & $1.37 \pm 0.17 \mathrm{~b}$ \\
\hline A21 (ठ) & $\mathrm{N}$ & $\mathrm{N}$ & $\mathrm{N}$ & $\mathrm{N}$ & $0.84 \pm 0.11 \mathrm{a}$ & $0.95 \pm 0.13 \mathrm{a}$ & $1.23 \pm 0.18 \mathrm{a}$ \\
\hline A $21(q)$ & $\mathrm{N}$ & $0.46 \pm 0.11$ & $0.47 \pm 0.13$ & $0.48 \pm 0.13$ & $0.75 \pm 0.12 b$ & $0.88 \pm 0.15 b$ & $1.41 \pm 0.14 \mathrm{~b}$ \\
\hline
\end{tabular}

${ }^{*}$ For abbreviations see Table 2. The sample numbers of males and females are 30 and 30, respectively. N: non-separation, $P<0.05$.

Table 8. The re-separation type of dorsal fin on marine medaka, Oryzias dancena

\begin{tabular}{|c|c|c|c|c|c|}
\hline & \multicolumn{5}{|c|}{ Type } \\
\hline & 1 & 2 & 3 & 4 & 5 \\
\hline $\begin{array}{c}\text { Re-separation } \\
\text { type }\end{array}$ & & & & & \\
\hline
\end{tabular}

The separation of dorsal fin had more special phenomenon than the result of anal fin and it is re-separation of fin rays with separation which randomly happened. The five type of re-separation (Table 8 ) and its appearance frequency were analyzed in Table 9. In case of D1, there was no separation for male and female, and for D2, male had type 1 and type 3 while female had type 1 so the re-separation barely happened. In case of D3, there was hardly any reseparation for male and low frequency of type 2 and 3 and the result was similar for both male and female. In case of D4, male and female showed opposite result that similar frequency for type 1 and 4 in female while male had high type 1 frequency. The result for D5 showed the vice versa result of D4 for male and female that high-similar frequency of type 1 and 4 for male and high frequency of type 4 for female. The result D6 showed similar trend as D5 and D7 showed similar high frequency of type 1 for male and female.

\section{DISCUSSION}

Every measured morphometric characteristic of marine medaka, Oryzias dancena showed a difference in growth 70 days after the incubation. Among these, direct distance between the anterior insertion of the first dorsal fin and the anterior insertion of the first anal fin (DADAA), direct distance between the posterior insertion of the last dorsal fin and the anterior insertion of the first anal fin (DPDAA), direct distance between the anterior insertion of the first dorsal fin and the posterior insertion of the last anal fin (DADPA), length of the fin rays of the dorsal fin (LFRsD), and length of the fin rays of the anal fin (LFRsA) had an apparent difference, and male characteristics were larger than female characteristics. Morphometrics were measured year round, and no difference in the growth was detected. Some experiments reported the differences in measured characteristics depending on whether measurements were 
Table 9. The re-separation frequency of dorsal fin on marine medaka, Oryzias dancena between male and female*

\begin{tabular}{|c|c|c|c|c|c|c|c|}
\hline $\begin{array}{l}\text { Re-separation } \\
\text { type }\end{array}$ & D1 & D2 & D3 & D4 & D5 & D6 & D7 \\
\hline \multicolumn{8}{|c|}{ Male } \\
\hline 1 & 0 & 55 & 70 & 80 & 35 & 30 & 55 \\
\hline 2 & 0 & 0 & 5 & 0 & 10 & 0 & 20 \\
\hline 3 & 0 & 40 & 25 & 20 & 20 & 20 & 0 \\
\hline 4 & 0 & 5 & 0 & 0 & 35 & 40 & 0 \\
\hline 5 & 100 & 0 & 0 & 0 & 0 & 5 & 25 \\
\hline \multicolumn{8}{|c|}{ Female } \\
\hline 1 & 0 & 95 & 55 & 40 & 15 & 5 & 55 \\
\hline 2 & 0 & 0 & 10 & 15 & 10 & 15 & 20 \\
\hline 3 & 0 & 5 & 15 & 5 & 5 & 0 & 0 \\
\hline 4 & 0 & 0 & 20 & 40 & 70 & 80 & 30 \\
\hline 5 & 100 & 0 & 0 & 0 & 0 & 0 & 0 \\
\hline
\end{tabular}

*The sample numbers of males and females are 30 and 30 , respectively. Data were converted into a percentage.

conducted during the spawning season. In the sexual dimorphism test of Korean chub, Zacco koreanus, 12 characteristics had a difference in males and females among the 37 characteristics measured in the spawning period, while only 1 characteristic had a difference between sexes in the non-spawning period (Kim et al., 2008).

Among the characteristics with apparent differences, differences in classical dimensions were not found. Classical dimensions were applied in the majority of studies measuring characteristics of fish during the past 30 years. Such classical dimensions focus on the length, width and height of fish, as well as mainly focusing on the axis of the fish body, including the tail and head part (Straüss \& Bond, 1990; Park et al., 2004). The results of this study showed differences in classical dimensions between sexes of marine medaka, but no clear and apparent difference was detected.

Apparent differences between sexes included the truss dimensions DADAA, DPDAA and DADPA. The truss dimension is a method to divide the fish body in functional units to investigate parts of appearance (Straüss \& Bond, 1990). This method complements the vertical measuring characteristics when characteristics are measured in classical dimensions by measuring across the body shape, and it also determines the body in network type (Park et al., 2004). The male marine medaka has a larger standard length and appearance than the female with respect to the middle of tail that is connected to the body of fish. The truss dimension is applied to determine the characteristics of Rhynchocypris oxycephalus when they are starved or satiated (Park et al., 2004). In this experiment, there was a change from the main body and rear body to the tail, which indicates that different food supplies were provided in the different environments inhabited by $R$. oxycephalus. Conversely, because no difference is shown between hungry and satiated $R$. oxycephalus under the head, this measurement can be used as an index of Rhynchocypris (Park et al., 2001a). Additionally, in a Korean chub sexual dimorphism experiment, the female had a higher index in direct distance between the insertion of the dorsal fin and the insertion of the anal fin (IDF-IAF), and the female also had a greater height than the male (Kim et al., 2008).

The dorsal fin and anal fin characteristics of the marine medaka showed significant differences between males and females. In particular, the results for the dorsal fin were similar to those of Park et al. (2001b). The result of an investigation measuring characteristics between sexes of the cocktail wrasse, Pteragogus aurigarius, by Park et al. (2001b) showed that there was a significant difference in the length of the first fin ray of the dorsal fin (LFDF1) and the length of the second fin ray of the dorsal fin (LFDF2) by sexes. In male cocktail wrasses, changes in the first and second spiny rays of the dorsal fin are more pronounced in the breeding season and are not present in sexually immature fish. In male marine medakas, however, the dorsal fin and anal fin are always larger than in the female. In other words, marine medakas do not show changed ratios of the 
dorsal fin rays and the anal fin rays in spawning season and breeding season because marine medakas spawn all year. As mentioned in Park et al. (2012), during spawning, the male marine medaka stacks his anal fin, the anal fin of the female marine medaka, his dorsal fin and then her dorsal fin. The body of the female is covered by the dorsal and anal fins of the male. Spawning then begins after covering is completed (Park et al., 2012). For this reason, the dorsal fin length and anal fin length of the male are higher than those for the female.

Sexual dimorphism is a component of external morphological variation between the sexes along with features such as the genital papilla, body pigmentation and fin shape (Kim $\&$ Kim, 2001). Sexual dimorphism is the most conspicuous difference between the sexes (Kim et al., 2008), and it is observed in many fish species. Females are usually larger than males of the same age. However, in some species like gudgeon, Gobio gobio and filefish, Brachaluteres ulvarum, males are larger than females (Mann, 1980; Akagawa et al, 1995). The reason for this size difference is not clear (Katano, 1998). Several authors have reported that the evolution of larger body size in male likely results from male-male competition associated with a polygynous mating system (Katano, 1998; Kim et al., 2008). Hence, exploring the nature and extent of sexual dimorphism can aid in the understanding of the social structure and adaptation of a species while also enabling more accurate species identification.

The characteristics of a dorsal fin and anal fin of marine medaka showed significant differences between males and females. As mentioned by Kim et al. (2009b), sexual dimorphism of marine medaka was possible to easily classify through forms of the dorsal fin and the anal fin. The result of Kim et al. (2009b) was similar to those of this research. In addition, the results of dorsal fin were similar to those of Park et al. (2001b). The result of the investigation of meauring characters between sexes of cocktail wrasse, Pteragogus aurigarius by Park et al. (2001b) showed that there were signifi- cant differences in the length of the first ray and length of the second ray of the dorsal fin by sexes. In male cocktail wrasse, changes in the first and second spiny rays of the dorsal fin are more pronounced in the breeding season and are not present in sexually immature fish. In male marine medaka, however, the dorsal fin and anal fin are always larger than female.

In some species in which the males provide parental care, Cottus amblystomopsis (Berg, 1932) and C. hangiongensis (Goto, 1984), the pelvic and pectoral fin lengths and the mouth size are distinctly greater in males than in females. During the spawning season, males of these species attract females to spawn, and subsequently defend the nest from intruders and fan the eggs with their pectoral or pelvic fins. In contrast, male Zacco leave the nest after spawning without providing parental care, and many satellites (both males and females) prey upon the eggs at the instant of spawning (Katano, 1998). The pectoral and pelvic fins (including the anal fin) do not seem to play a functional role in the protection of eggs through fanning (Kim et al., 2008). In other words, marine medaka didn't change tendency of the dorsal fin rays and the anal fin rays in spawning season and breeding season, because marine medaka has all year round spawn (Park et al., 2012).

In this study, when classical dimensions and truss dimensions were measured, the male marine medaka had more rapid growth than the female, with longer length, longer dorsal fins, and longer anal fins. Moreover, the structural difference of male and female was clearly seen separation and re-separation of fin rays. Differences in these characteristics will be useful during experiments when it is necessary to differentiate between sexes of marine medaka. These measurements and characteristics can also be used as an index to classify Cyprinodontidae. Based on the results of this study, further inquiry might determine the difference in the external measurement characteristics between artificially induced diploid and triploid marine medaka. 


\section{ACKNOWLEDGEMENTS}

This work was supported by a grant from the National Institute of Fisheries Science (R2016039) from the Inland Fisheries Research Institute, National Institute of Fisheries Science (NIFS), Korea. The authors thank the technical staff of the Cheongpyeong Aquaculture Research Center, NIFS, Korea, and the Laboratory for Fishery Genetics and Breeding Sciences at Korea Maritime University, Korea, for their helpful support, and the anonymous reviewers who greatly improved the quality of this manuscript. All procedures used in this study complied with current laws of Korea (Ordinance of Agriculture, Food and Fisheries, No. 1 and the law pertaining to experimental animals, No. 9932).

\section{REFERENCES}

Akagawa I, Tsukamoto Y, Okiyama M (1995) Sexual dimorphism and pair spawning into a spnge by the filefish, Brachaluteres ulvarum, with a description of the eggs and larvae. Japan J Ichthyol 41:397-407.

Anderson M (1994) Sexual Dimorphism. University of Princeton Press, New Jersey.

Berg LS (1932) A review of the freshwater cottoid fishes of Pacific slope of Asia. Copeia 1932:17-20.

Goo IB, Im JH, Gil HW, Lim SG, Park I-S (2015) Comparison of cell and nuclear size difference between diploid and induced triploid in marine medaka, Oryzias dancena. Dev Reprod 3:127-134.

Goto A (1984) Sexual dimorphism in a river sculpin Cottus hangiongensis. Japan J Ichthyol 31:161-166.

Hubbs CL, Lagler KF (1947) Fishes of the Great Lakes region. Cran Insti Sci Bull 26:1-186.

Inoue K, Takei Y (2003) Asian medaka fishes offer new models for studying mechanisms of seawater adaptation. Comp Biochem Physiol B-Biochem Mol Biol 136:635-645

Kang CK, Tsai SC, Lee TH, Hwang PP (2008) Differential expression of branchial $\mathrm{Na}^{+} / \mathrm{K}^{+}$-ATPase of two medaka species (Oryzias latipes) and (Oryzias dancena), with different salinity tolerances acclimated to fresh water, brackish water and seawater. Comp Biochem Physiol A-Mol Integr Physiol 151:566-575.

Katano O (1998) Growth of dark chub, Zacco temmincki (Cyprinidae), with a discussion of sexual size differences. Environ Biol Fish 52:305-312.

Kim DS, Nam YK, Bang I-C, Song HY (2009a) Early gonadogenesis and sex differentiation of marine medaka, Oryzias dancena (Beloniformes; Teleostei). Kor J Ichthyol 21:141-148 (in Korean with an English abstract).

Kim DS, Nam YK, Bang I-C, Song HY (2009b) Embryogenesis and early ontogenesis of a marine medaka, Oryzias dancena. Kor J Ichthyol 21:227-238 (in Korean with an English abstract).

Kim YJ, Kim JM (2001) Sexual dimorphism of three species of genus Gymnogobius (Gobiidae) from Korea. Kor J Ichthyol 13:117-122.

Kim YJ, Zhang CI, Park I-S, Na JH, Olin P (2008) Sexual dimorphism in morphometric characteristics of Korean chub, Zacco koreanus (Pisces, Cyprinidae). J Ecol Field Biol 31:107-113.

Mann RHK (1980) The growth and reproductive strategy of the gudgeon, Gobio gobio (L.), in two hard-water rivers in Southern England. J Fish Biol 17:163-176.

Nam YK, Cho YS, Lee SY, Kim DS (2010) Tolerance capacity to salinity changes in adult and larva of Oryzias dancena, a euryhaline medaka. Kor J Ichthyol 22:9-16 (in Korean with an English abstract).

Park E-H, Kim DS (1984) A procedure for staining cartilage and bone of whole vertebrate larvae while rendering all other tissues transparent. Stain Tech 59:269272 .

Park I-S, Gil HW, Baek HM, Kim DS, Nam YK (2012) Observations on the spawning behavior of the marine medaka, Oryzias dancena. Kor J Ichthyol 24:220-226.

Park I-S, Gil HW, Oh JS, Choi HJ, Kim CH (2015) Com- 
parative analysis of morphometric characteristics of Scorpaenidae and Gobioninae. Dev Reprod 2:85-96.

Park I-S, Im JH, Hur JW (2004) Morphometric characteristics of catfish (Siluridae) in Korea. Kor J Ichthyol 16: 223-228.

Park I-S, Im JH, Ryu DK, Nam YK, Kim DS (2001a) Effect of starvation on morphometric changes in Rhynchocypris oxycephalus (Sauvage and Dabry). J Appl Ichthyol 17:277-281.

Park I-S, Park SJ, Gil HW, Nam YK, Kim DS (2011) Anesthetic effects of clove oil and lidocaine- $\mathrm{HCl}$ on marine medaka, Oryzias dancena. Lab Animal 40:45-51.

Park I-S, Woo SR, Song Y-C, Cho SH (2007) Effects of starvation on morphometric characteristics of olive floun- der, Paralichthys olivaceus. Ichthyol Res 54:297-302.

Park I-S, Zhang CI, Lee Y-D (2001b) Sexual dimorphism in morphometric characteristics of cocktail wrasse. J Fish Biol 58:1746-1749.

Roberts TR (1998) Systematic observations on tropical Asian medakas or ricefishes of genus Oryzias, with descriptions of four new species. Ichthyol Res 45:213-224.

Straüss RE, Bond CE (1990) Taxonomic methods, morphology. In: Methods for Fish Biology (Schreck, C.B., Moyle, P.B., eds), pp. 125-130. Bethesda, Maryland: American Fish Society.

Straüss RE, Bookstein FL (1982) The truss: body from reconstructions in morphometrics. Syst Zool 31:113-135. 